\title{
Los intelectuales españoles ante los acontecimientos de Marruecos en 1911. (Un episodio en la crítica o inclinación de España hacia Francia)
}

\author{
Miguel Ángel García de Juan ${ }^{1}$
}

Recibido: 21 de diciembre de 2016 / Aceptado: 16 de mayo de 2017

Resumen. Las acciones y manifestaciones de fuerza militares en Marruecos en 1911 por parte de Francia, España y Alemania estuvieron a punto de provocar un conflicto armado internacional. Cada país de los citados acusó al otro de haber ido a Fez, Larache Alcazarquivir o Agadir con el pretexto de socorrer a sus protegidos. Los intelectuales españoles tomaron partido mayoritariamente contra la primera en sus colaboraciones periodísticas, fuente principal del presente trabajo. La aportación de éste radica en recordar lo sucedido en aquel crucial 1911, pues la historiografía española ha pasado, en gran parte, con demasiada rapidez sobre ello. Con todo, su primordial fin es reflejar, a partir de la prensa, un episodio más de las discrepancias entre Francia y España, ahora con ocasión de las intervenciones en el norte de África, al cual se ha prestado muy poca o ninguna atención. Por otro lado, cabe poner de relieve que la falta de criterio común en las opiniones de los intelectuales provocó en ciertos casos alguna agria discusión.

Palabras clave: Marruecos 1911. Francia. Alemania. Prensa. Intelectuales españoles.

\section{[en] The Spanish Intellectuals faced with the Events in Morocco 1911. (An Epi- sode in Connection with the Spain's Criticism or Inclination towards France)}

\begin{abstract}
The armed forces's acts and statements in Morocco 1911 coming from Spain, France and Germany, were about to cause an international armed conflict. Each country accused the others of having arrived in Fez, Larache, Alcazarquivir or Agadir under the pretext of helping their "protégés". The Spanish intellectuals in general took sides against France when writing journals, main source for this essay. It's contribution is based on remembering what happened in that crucial 1911, because the Spanish historiography has passed too quickly over that event. Nevertheless, the first aim of this work is to show, from the newspapers, one more episode of the discrepancies between France and Spain about the intervention, poorly studied so far. On the other hand, should be emphasised the lack of common criterion among the intellectuals, whose opinions sometimes provoked some sour discussions.
\end{abstract}

Keywords: Morocco 1911, France, Germany, Press, Spanish intellectuals.

Sumario. Introducción. 1. Los intelectuales en España a finales del siglo XIX y comienzos del XX 2. Jacinto Benavente 3. Ramiro de Maeztu 4. Pío Baroja 5. José Ortega y Gasset 6. Manuel Azaña 7. Conclusión 8. Referencias bibliográficas 8.1. Prensa 8.2. Fuentes secundarias.

Cómo citar: García de Juan, M. A. (2017). "Los intelectuales españoles ante los acontecimientos de Marruecos en 1911. (Un episodio en la crítica o inclinación de España hacia Francia)”. Cuadernos de Historia Contemporñanea, 39, 213-241.

1 IES Rosa Chacel, Madrid (España)

E-mail: somi.85@hotmail.com 


\section{Introducción}

Perdidas las colonias de ultramar en 1898, España centró su política exterior en Marruecos, donde muy debilitada militarmente, con una economía muy depauperada y con la opinión pública desalentada tuvo que afrontar el expansionismo colonialista francés. Y es que, tras la conferencia de Algeciras de 1906, el país vecino se consideró autorizado para ampliar sus zonas de influencia a costa de cualquier potencia europea. De todos modos, pasado un lustro, de la firma de la aludida "Acta", algunas instituciones, periodistas, partidos y periódicos determinaron responder a las pretensiones y acciones francesas, especialmente alentadas por el partido colonial y la prensa expansionista galos.

Así, el año 1911 comenzó con la visita a Melilla, el 10 de enero, del rey Alfonso XIII ("el africano"2), la cual fue criticada por la prensa francesa colonial, es decir, por casi toda ella, y más aún que el presidente del Gobierno José Canalejas, que lo acompañaba, dijera ese mismo día, en la clausura de las reuniones de las cámaras de comercio españolas celebradas allí "Si perdimos América, aquí está el África, y en ella defenderemos nuestros derechos mientras nos quede un hálito de vida"

Pues bien, la tensión entre Francia y España, sobre todo en el terreno de la Prensa, fue subiendo de tono cuando la segunda consideró que las aspiraciones de aquélla amenazaban las zonas de influencia españolas establecidas en Algeciras o que el ejército francés se desplegaba por territorios marroquíes sobre los que no tenía ningún derecho. En consecuencia, al llegar las tropas del general Moinier a Fez el 21 de mayo, a petición del Sultán, con el objeto de sofocar la sublevación de algunas cabilas, aquéllas, pasado un tiempo, no se retiraron de la ciudad. España, aduciendo la misma razón de Francia de restaurar y mantener el orden en Larache y Alcazarquivir, envió allí sus soldados, los cuales desembarcaron en la primera localidad el 4 de junio. Si en la cuestión de Fez los periódicos españoles habían protestado por la ida francesa a la capital religiosa del Imperio y el gobierno de Canalejas se mantenía a la expectativa de los movimientos de las fuerzas de la República, ahora eran los diarios de ésta y el Consejo de Ministros galo los que censuraban la acción de España.

Pero la pugna en el norte de África en 1911 no se redujo a la mantenida entre Francia y España sino que, llegado el 1 de julio a Agadir el cañonero germano Panther, con el mismo supuesto alegado antes por Francia y España de apaciguar sus zonas de influencia, Alemania entró en el litigio.

Tras las esperadas reacciones de Francia contra Alemania, pronto se avinieron a entablar relaciones para establecer un acuerdo, al que llegarían el 4 de noviembre. De aquéllas y éste quedó excluida por completo España. Además, la prensa francesa

2 Recuerda Manuel Suárez Cortina en La España liberal (1868-1917). Politica y sociedad, Madrid, Síntesis, 2006, p. 273: “[Después de 1898] Marruecos pasó a ser el eje de la política exterior de la España alfonsina. No en vano se llamó al rey Alfonso "el africano", dada su proclividad a fortalecer la acción colonial en la zona". Información detallada de las acciones de España en el norte de África en 1911 y 1912 se halla en Gonzalo Calvo: España en Marruecos (1910-1913), Barcelona, Casa editorial Maucci, 1914. Más sucinta, sobre lo ocurrido allí en 1911 relacionado con España, puede leerse en Carlos Seco Serrano: Historia de España de Menéndez Pidal, tomo XXXVIII, vol. 1, Madrid, Espasa Calpe, 1996, pp. 229-286 ("El año de la gran prueba: 1911”, lo llama este significado historiador, p. 227); y en Gonzalo Terreros: Las guerras de Marruecos, Barcelona, Erasmus Ediciones, 2014. Con alguna mayor amplitud que los dos anteriores lo trata recientemente José Luis Loureiro Souto: Los conflictos por Ceuta y Melilla: 600 años de controversias, Instituto Universitario General Gutiérrez Mellado-UNED, 2015, pp. 386-406.

3 Ver El Telegrama del Rif del día 11, p. 2. 
reclamaba que la nación del sur fuera desposeída de parte de su territorio africano bajo la acusación malintencionada de haber sido la causante del arribo de Alemania a Agadir. He aquí lo que decía el más beligerante diario francés contra España, el colonialista Le Temps del día 22 de octubre, en su página segunda:

Comme Le Temps l'a souvent montré, l'Espagne, à tant d'agitation, n'aura gagné que l'isolement. Elle n'a obtenu de l'Allemagne aucune garantie pour ses prétentions marocaines. Elle a brisé les liens qui l'unissaient à la France et à l'Angleterre. Il est naturel, dans ces conditions, que la France, même si elle ne va pas jusqu'au but de son droit qui serait de dire à l'Espagne: «Vous avez rompu les traités, je ne vous reconnais plus rien», prenne pour l'avenir de rigoureuses précautions.

Pero a España le quedaba jugar la baza de su relación con el Reino Unido, el cual no podía permitir que los dominios franceses se aproximaran a territorios en los que mantenía intereses tan estratégicos como Gibraltar.

Es en este contexto de la segunda mitad de año 1911 en el que Jacinto Benavente, Ramiro de Maeztu, Pío Baroja, José Ortega y Gasset y Manuel Azaña publican sus colaboraciones periodísticas a favor o en contra de unas u otras potencias o de algunos aspectos de ellas ${ }^{4}$. Dejando a un lado al variable Benavente, quien se mostró más antifrancés fue Pío Baroja; Maeztu se decantó por Alemania y el Reino Unido; Ortega y Gasset se manifestó progermano y tibio con Francia. El que se mostró francófilo, sin reservas, fue Manuel Azaña, pues defendió que Francia era el modelo que se había imitado en Europa y había que continuar haciéndolo.

\section{Los intelectuales en España a finales del siglo XIX y comienzos del XX}

Desde que E. Inman Fox abordara en 1975 la cuestión del significante y significado del nombre "intelectual" tal como lo entendemos hoy, todos los que han tratado después del asunto de los intelectuales de finales del siglo XIX y comienzos del XX en España han seguido su estela ${ }^{5}$. En la aludida investigación afirma su autor:

Según nuestras indagaciones, el uso de de "intelectual" como sustantivo entró definitivamente en la lengua castellana casi al mismo tiempo que en la francesa, a raíz de la organización de los profesores y escritores franceses en torno al asunto Dreyfus. [...] La palabra estaba lanzada y es verdaderamente asombrosa la frecuencia del uso del neologismo "intelectual" durante los primeros meses de $1898^{6}$.

4 En honor de la verdad hay que decir que el vitoriano ya había escrito en mayo, en torno a la acción de la República en Fez, varios artículos críticos con Francia.

5 "El año 1898 y el origen de los intelectuales", de E. Inman Fox, se publicó por vez primera en La crisis de Fin de siglo: ideología y literatura (Estudios en memoria de R. Pérez de la dehesa), Barcelona, Ariel, 1975, pp. 17-24. Se reprodujo después en su libro: La crisis intelectual de 98, Madrid, Cuadernos para el Diálogo, 1976. Finalmente, una versión ampliada pasó a formar parte del volumen: Ideología y política en las letras de Fin de siglo (1898), Madrid, Espasa Calpe, 1988, pp. 13-23, por donde se harán las citas correspondientes.

6 Fox, E. Inman: Ideología y política..., p. 15. Entre quienes han continuado por el camino abierto por el hispanista estadounidense, puede citarse a Carlos Serrano, quien afirma: "El 'intelectual' es un claro producto del dramático final del siglo, al que sirve de modelo el affaire Dreyfus, con su partido de "intelectuales"”: "Los ‘intelectuales’ en 1900 ¿Ensayo general?’, en Salaün, Serge y Serrano, Carlos (eds.): 1900 en España, Madrid, Espasa Universidad, 1991, p. 86. Poco tiempo después, Santos Juliá manifestaba que hay acuerdo "unánime" 
Añade Fox que, tras haber rastreado con detalle los escritos krausistas, regeneracionistas, noventayochistas y componentes de la generación anterior, no cabe duda de que fueron los del "98" los que asimilaron y comenzaron a emplear, traducida del francés, la palabra "intelectual" con el significado de "influir culturalmente en el rumbo del país" utilizarla con asiduidad, además, atribuyéndosela a sí mismos. (De ellos, entre otros, se ocupará el presente trabajo en relación con la cuestión hispano-franco-marroquí de 1911). En efecto, en el artículo "La vida es sueño. Reflexiones sobre la regeneración de España", publicado a finales de 1898 en La España Moderna, escribía Miguel de Unamuno: "En rigor, no somos más que los llamados, con más o menos justicia, intelectuales y algunos hombres políticos, los que hablamos ahora a cada paso de la regeneración de España. Es nuestra última postura, el tema de última hora ${ }^{8}$. Por su parte, Ramiro de Maeztu cerraría con las siguientes palabras su artículo "La Cruz de la Espada", publicado el 27 de agosto de 1899 en Vida Nueva: "Y entonces, vosotros, intelectuales de Cristo y de Comte, y de Reclus y de Marx, iQuedad con la Cruz! Y nosotros, intelectuales de Wotan y de Júpiter, esgrimiremos la hoja, e hincándola en el corazón de los que sufren, domeñaremos definitivamente la tristeza, la ignorancia y la miseria humanas".

Hora es ya de atender al significado que tiene desde finales del siglo XIX y comienzos del XX el sustantivo "intelectual", con el fin de ver si es apropiado, como parece serlo hasta aquí, conferírselo a aquellos miembros de las generaciones del " 98 " y del "14" de los cuales se tratará en los capítulos siguientes de esta investigación.

De la abundancia de definiciones de "intelectual" se desprende la dificultad de delimitar su significado. Así, para Eric Storm, por ejemplo, aquél es "un profesional del campo cultural, que, desde una posición independiente, con el solo prestigio

en que "intelectual" apareció como sustantivo en la década de 1890 y, a partir del caso Dreyfus se extendió por España: "Literatos sin pueblo: La aparición de los intelectuales españoles", Studia Historica, Historia Contemporánea, 16, 1998, p. 108. Este artículo lo modificó y (o) amplió en "Intelectuales y Prensa en el siglo XX”, en Almuiña, Celso y Sotillos, Eduardo (coords.): Del periódico a la sociedad de la información, Madrid, Sociedad Estatal Nuevo Milenio, Madrid, 2002, pp. 197-218; y en su libro Historia de las dos Españas, Madrid, Taurus, 2004. En los citados trabajos, Santos Juliá se ocupa de la relación entre el "intelectual”, tuviera ya o no este nombre y la evolución de la sociedad, interesante cuestión que aquí nos desviaría de nuestro propósito. Por su parte, Eric Strom afirma tajantemente: "La figura del intelectual vio la luz con la publicación de la carta de Émile Zola, L'Aurore, el 13 de enero de 1898": "Los guías de la nación. El nacimiento del intelectual en el contexto internacional", Historia y política, número 8, 2002, p. 39.

7 Fox, E. Inman: Ideología y política..., p. 18. El investigador norteamericano declara que sólo ha encontrado el sustantivo "intelectual" antes de 1898, precisamente en dos de los noventayochistas: Unamuno, que lo utilizó en una carta a Cánovas del Castillo el 28 de noviembre de 1896, y Ramiro de Maeztu, que la llevó al artículo "El socialismo bilbaíno", de Germinal, el 16 de julio de 1897 , pp. 7 y 8.

8 Unamuno, Miguel de: "La vida es sueño. Reflexiones sobre la regeneración de España”, La España Moderna, 10 de noviembre de 1898, tomo 119, p. 69. Precisamente, Ramiro de Maeztu, en su libro recopilatorio Hacia otra España, publicado a comienzos de 1898, había dicho de su paisano vasco: "En cabezas como la de Unamuno caben los embriones de un centenar de literaturas y filosofías nuevas. La lucha entre el temperamento místico y el hábito de análisis lógico, la pugna entre el hombre y el intelectual [...], todo se encuentra en ese bilbaíno colosal, aunque atropellado", Madrid, Biblioteca Nueva, 1899, p. 200.

9 En el artículo "La nueva guerra" de Vida Nueva, 17 de julio de 1898, p. 3, firmado por Pío Quinto y anterior a los de Unamuno y Maeztu, hemos encontrado la palabra "intelectual” entrecomillada, aunque no referida a sí mismo, sino más bien con connotaciones satíricas. Dice el que se oculta detrás del seudónimo, a propósito de la división en tres grupos de quienes se dejan captar por los jesuitas: "La segunda clase, 'la intelectual': escritores periodistas, empleadillos, gente con trazas de clase media”. El artículo se le ha atribuido hasta hace muy poco tiempo a pío Baroja, pero, según las recientes investigaciones de José Bernardo San Juan, detrás de Pío Quinto se esconden el clérigo José Fernández Ruiz o el periodista Dionisio Pérez. Véase: Estudio de la Revista Vida Nueva (1898-1900) y descripción de la crítica literaria en sus páginas, Madrid, Universidad Complutense, 2013. 
de su nombre, intenta influir en el rumbo político del país, apelando a la opinión pública" ${ }^{10}$. Sin embargo, denominar de ese modo al intelectual adolece de, al menos, dos defectos: ni éste ha de proceder siempre del "campo cultural", ni tiene por qué ser siempre independiente ${ }^{11}$. En consecuencia, quizá fuera más acertado considerar al intelectual como una persona del mundo de las ciencias experimentales o sociales y las humanidades, normalmente de estas dos últimas, que pronuncia discursos o conferencias, escribe libros (creativos o no) y publica artículos ocasionales o habituales en la prensa con la intención de influir, en mayor o menor medida, en los receptores. Por tanto, los intelectuales no han de ser asociados exclusivamente al terreno de las humanidades y menos aún a las específicamente creativas. Con razón afirmaba Unamuno en 1905, en su artículo “¿Quiénes son los intelectuales?”: "Lo que quiero hacer notar aquí es que de cada veinte veces que se habla de intelectuales, las diecinueve se habla de literatos, de autores de poesía, dramas o novelas. Apenas se llaman a sí mismos intelectuales sino los literatos"12. En consecuencia, tan estimados como intelectuales han de ser el filósofo José Ortega y Gasset y el jurista Manuel Azaña como el dramaturgo Benavente, el novelista Pío Baroja y el periodista Ramiro de Maeztu. (De todos ellos nos ocuparemos en las páginas siguientes).

Por lo que se refiere a la independencia que, según Storm debe adornar al intelectual, hay que decir que todos los citados escribieron en 1911, año en que le centra el presente trabajo, en diarios comprometidos ideológicamente; es decir, ligados a partidos políticos. El Imparcial, en el que colaboraron Benavente, Pío Baroja y José Ortega y Gasset, se hallaba vinculado al Partido liberal de José Canalejas y dirigido por su correligionario y diputado Luis López Ballesteros; así que era lógico que quienes escribían en él apoyaran las medidas adoptadas por el Gobierno en Marruecos y rechazaran los ataques de la prensa francesa por haberlas tomado. Por su parte, Heraldo de Madrid, en el que firmaba artículos Ramiro de Maeztu, pertenecía también a la órbita de dicho Partido, pero inclinado a la izquierda. Lo dirigía José Rocamora, buen conocedor de las aspiraciones francesas en Marruecos por haber sido corresponsal en Algeciras durante la Conferencia de $1906 \mathrm{y}$, luego, informador en la campaña de Melilla de $1909^{13}$. Finalmente, La Correspondencia de España, el periódico en el que colaboró Manuel Azaña, el de mayor tirada del país ${ }^{14}$, aspiraba a mantener un equilibrio entre derechas e izquierdas, pero con propensión a decantarse por éstas. Como era partidario del abandonismo colonial español, quedó al margen de enfrentarse a las críticas de la prensa francesa contra la política exterior española en África. Lo dirigía el diputado por Zaragoza Leopoldo Romeo (“Juan de Aragón”). En cuanto a Nuevo Mundo, revista en la que colaboró también Ramiro de Maeztu en

10 Storm, Eric: "Los guías de la nación...", p. 48.

11 Alberto Reig Tapia recuerda que ya desde el affaire Dreyfus hubo quienes se mostraron a favor del militar como Zola, Clemenceau o Jaurés y quienes manifestaron su oposición a que se revisara la sentencia condenatoria. Tal fue el caso de Maurice Barrés: "Los intelectuales y la guerra civil española. Los casos de Unamuno y Baroja", Historia Contemporánea, 35, 2007, p. 602.

12 Unamuno, Miguel de: “¿Quiénes son los intelectuales?”, Nuevo Mundo, 13 de julio de 1905, p. 5.

13 Alejandro Pizarroso recuerda que, firmado el "trust" periodístico, en 1906, los principales diarios que lo componían seguían manteniendo su trayectoria ideológica: El Imparcial, liberal dinástico; El Liberal, republicano y progresista; el Heraldo, progresista y muy popular": "Los medios de comunicación social 18751939”, en Ángel Bahamonde (coord.): Historia de España. Siglo XX, 1875-1939, Madrid, Cátedra, 2000, p. 702.

14 La cifra corresponde a 1913, al igual que las que se detallan a continuación. Heraldo de Madrid se situaba en segundo lugar, con una tirada de 125000 ejemplares. El Imparcial imprimía 83 000. Véase Seoane, María Cruz y Sáiz, María Dolores: Historia de la prensa en España, 3. El siglo XX: 1898-1936, Madrid, Alianza, 1983, p. $71-74$. 
1911, se dirigía a la clase media y media alta, algo más avanzada ideológicamente que la de su competidora Blanco y negro ${ }^{15}$.

En lo que atañe a cuánta pudo ser la audiencia de los artículos escritos en 1911 a propósito de la cuestión hispano-francesa-marroquí de ese año por los intelectuales a los que vinimos refiriéndonos, si se piensa en que, de los veinte millones de españoles, aproximadamente la mitad era analfabeta y en que sólo el veinte por ciento de los habitantes vivían en las ciudades, se deduce que no pudo alcanzar grandes tasas $^{16}$. Por el contrario, debieron de tener numerosos lectores entre los alfabetizados, sobre todo gentes instruidas y del mundo de la política; o sea, los dirigentes de la nación. Y es que de los del "98", todo eran muy conocidos: Jacinto Banavente ya había estrenado su obra maestra, Los intereses creados, en 1907; Maeztu no cesaba de publicar artículos en unos y otros periódicos; Pío Baroja había sacado a la luz dos de sus novelas más famosas: La busca (1903 y 1904) y Zalacaín el aventurero (1909). Aunque más jóvenes, José Ortega y Gasset, venía publicando artículos en el diario de la familia, El Imparcial, o en otros, desde 1904; Manuel Azaña, que había ingresado en el Ateneo en 1900, era uno de los miembros más activos, pronunciando conferencias o escribiendo algunos artículos periodísticos.

Los diarios en que escribían estos intelectuales aspiraban, como todos, a ganar lectores, bien incorporando nuevos alfabetizados, bien atrayéndolos de la competencia. Asimismo, los periódicos vinculados a partidos políticos pretendían mantener y ganar votantes para su causa. Igualmente, se hallaba entre sus objetivos contrarrestar informaciones y opiniones de rotativos competidores, incluso adversarios, dentro y fuera de España (piénsese en los diarios coloniales franceses) y, también, demostrar su solidez contratando a los más significados intelectuales. Si a lo dicho unimos que éstos pretendían con sus colaboraciones que se conocieran sus opiniones y se participara de ellas, pues en palabras de María Gajate Bajo: "[Desde la Restauración] el diario se convirtió en el ámbito natural del pensador, con un papel considerablemente más importante que el desempeñado por el libro"17, además de consolidar su prestigio en mayor o menor medida reconocido y obtener un beneficio crematístico ${ }^{18}$, no cabe duda de que la existencia de las empresas periodísticas tenía mucho sentido. Así se comprende que, de 1347 diarios existentes en España en 1900, se pasara en 1980 , en $1913^{19}$.

Centrándonos ya en el Marruecos de 1911 y los escritores-intelectuales de la llamada generación del "98", resulta muy difícil o imposible encontrar artículos de Unamuno, Martínez Ruiz, Valle-Inclán y Antonio Machado publicados en ese año que traten de los acontecimientos en el sultanato y su preocupante repercusión en las

15 Urrutia, Manuel María. "Unamuno y la revista Nuevo Mundo (Artículos desconocidos)”, Cuadernos de la cátedra de Miguel de Unamuno, 34, 1999, pp. 161-162.

16 Alejandro Pizarroso señala en "Los medios de comunicación social...", p. 700, que en 1913 se publicaba en España un periódico por cada 15016 habitantes.

17 Gajate Bajo, María: "Unamuno y la cuestión de Marruecos. ¿Salvación patria o ruina absoluta?, en Barrio, Ángeles, Hoyos, Jorge de y Saavedra, Rebeca (coords.): Nuevos horizontes del pasado: culturas políticas, identidades y formas de representación, Santander, Universidad de Cantabria, 2011, p. 53.

18 A modo de ejemplo, Pío Baroja dejó Revista Nueva, de Ruiz Contreras, porque era muy poco conocida y, además, no ganaba nada con sus artículos. Decidió irse a El País o El Liberal, pues la difusión de estos era incomparablemente superior: "Eran periódicos muy leídos", dice en Final del siglo XIX y principios del XX, Madrid, Caro Raggio, 1982, p. 86. Y, en la página 290, añade, recordando el año 1902: "Por entonces escribí yo en la hoja del lunes (sic) de El Imparcial, que era para los escritores que empezaban una pequeña consagración periodística".

19 Pizarroso, Alejandro: "Los medios de comunicación...”, p. 700. 
potencias europeas causantes, a su vez, de ellos. Y es que no le falta algo de razón a Andrée Bachoud cuando afirma: "La evolución política de casi todos [los del 98] es perceptible desde 1909. Los textos que escriben entonces sobre Marruecos se caracterizan por su falta de interés por lo que sucede allí. Sin embargo, un decenio antes, todos se habían distinguido en la lucha contra las campañas coloniales de América"20.

Lo que dice Bachoud no se ajusta, en efecto, completamente a la realidad, pues Unamuno, Benavente y, sobre todo, Maeztu y Baroja sí se interesaron por el problema marroquí después de 1909. Lo mismo puede afirmarse de algunos intelectuales de la generación siguiente como Ortega y Gasset y Manuel Azaña.

Respecto a Miguel de Unamuno (el principal pensador y ensayista del grupo), procede recordar que, si bien no hemos hallado ningún escrito suyo en la prensa de 1911 relacionado con la cuestión marroquí, en él o en los años inmediatamente posteriores giró ciento ochenta grados desde el apoyo a la presencia de España en el norte de África, "pensador africanizante" lo llamó Luis Araquistain en 1910²1, hasta una posición opuesta por completo en $1915^{22}$.

\section{Jacinto Benavente}

El dramaturgo madrileño (el más significado autor de teatro de la Generación, después de Valle-Inclán) publicaba el 11 de septiembre de 1911, en el fragor de los artículos cruzados o no entre Ramiro de Maeztu, Pío Baroja, José Ortega y Gasset y Manuel Azaña, como se verá luego, una de sus colaboraciones en "Los lunes de El Imparcial", tituladas "De sobremesa". En ella manifestaba que, si hasta entonces había defendido que la alianza con Alemania sería la más beneficiosa para España, ahora creía que había que seguir a Francia. No obstante, a quien más debiera parecerse era a Italia: "[Si todos los pueblos latinos] son hermanos, sólo Italia es madre de todos, y, sobre todos, gloriosa".

20 Los españoles ante las campañas de Marruecos, Andrée Bachoud, Madrid, Espasa Universidad, 1988, p. 353.

21 «Los hombres del congreso laborista», La Mañana, 3 de abril de 1910, p. 3.

22 Información para conocer el pensamiento de Unamuno sobre las acciones coloniales españolas en Marruecos se encuentra en María Gajate Bajo, "Unamuno y la cuestión de Marruecos...", pp. 153-169. A la época de su deseo de presencia de España en África pertenece la carta del 15 de septiembre de 1909 en el $A B C$, p. 10 (firmada en Bilbao el día 13), en la que apoyaba otra de Azorín de tres jornadas anteriores, en la página 12 del mismo periódico titulada "Colección de farsantes". En ésta Martínez Ruiz arremetía contra los que, desde otros países, singularmente Francia, atacaban a España. En su misiva escribía Unamuno la famosa expresión "inventen ellos", en cuyo contexto queremos detenernos, pues, por lo general, ha sido mal interpretada, a lo que ha contribuido el añadido inicial de la conjunción "que", inexistente en el original. El rector de Salamanca no quería decir que a España no le interesaran los descubrimientos, que eso carecía de mérito y lo dejaba para otros países, sino que, si las demás naciones tenían a ésta por un país de segunda fila, sin capacidad para la ciencia, se dedicaran ellas a inventar, pues España tenía capacidad para aprovechar los descubrimientos, o sea, para beneficiarse de ellos: "Dicen que no tenemos espíritu científico. ¡Si tenemos otro...! Inventen ellos, y lo sabremos luego y lo aplicaremos". Las biografías más recientes sobre Unamuno no prestan atención al año 1911 ni a su evolución del africanismo al anticolonialismo. Colette y Jean-Claude Rabaté: Miguel de Unamuno. Biografia, Madrid, Taurus, 2004, se limitan a recoger brevemente algunas palabras de su artículo "Ambiente de guerra”, publicado el 8 de septiembre de 1909 en La Nación de Buenos Aires, a propósito de la guerra en el Rif. En opinión del rector de Salamanca, si España no hubiera entrado allí, lo hubiera hecho Francia, pues "codiciaba Marruecos". Y a propósito de la prensa gala, es "La que más patrañas esparce a cuenta de los españoles y la que con más hipócrita malevolencia los trata", p. 284. 
La volubilidad en el pensamiento de D. Jacinto quedaba de manifiesto al final de su colaboración habitual "De sobremesa" del 18 de septiembre, en la que se pronunciaba de este modo contra Francia:

Los franceses nos pondrán en solfa y, por eso, sin duda, padecen la obsesión musical de España. De diez o doce conciertos anunciados en días pasados, de los que dan en París continuamente las bandas militares, no había uno solo en que no figurara una pieza de inspiración española. La «España» de Chabrier; fantasías de "Carmen"; un "Vito"; fantasías de "El Cid", de Massenet; serenata española. Eso sí, entre tanta música española, ni un solo compositor español. Basta con que la inspiración sea nuestra, ellos se bastan para instrumentarlo todo. Lo mismo que en Marruecos, y en todas partes. Aquí cantamos y bailamos, ellos instrumentan...y $\operatorname{cobran}^{23}$.

El año siguiente, el 20 de agosto de 1912, su artículo "Por tierras de África" alababa la ciudad de Ceuta y la conducta del general Alfau. Además, solicitaba que se enviara allí más dinero y reprochaba a Francia las críticas a la misión de España en África, pues empezaba ya a comprenderse que, en nuestros tiempos y con más dificultades de todo género, hemos hecho más que los franceses ${ }^{24}$.

\section{Ramiro de Maeztu}

Entre todos los intelectuales del grupo del "98", quien mostró mayor interes por la cuestión marroquí en 1911 fue Ramiro de Maeztu (el periodista más prolífico junto a Azorín).

Desde muy joven se inclinó hacia el cosmopolitismo, pues vivió en varios países del Viejo y Nuevo continentes. Ya a sus dieciséis años viajó a París con intención de hacerse comerciante. Vuelto a España, en 1894 se trasladó a la Habana, de donde regresó tres años más tarde... Pero lo que interesa en este trabajo es su buen conocimiento de Francia, el Reino Unido y Alemania por haber residido allí, y ejercido en los dos últimos países de corresponsal de distintos diarios españoles, es decir, sus afirmaciones y pareceres en 1911 acerca de las tres naciones citadas se encontraban tan fundamentadas como las de aquellos que habían vivido o vivían en una o varias de ellas. Estos son los casos de Pío Baroja (Francia y Reino Unido) y José Ortega y Gasset (Alemania). Por tanto, sus opiniones se hallaban más cimentadas que las de los que no habían pasado por ninguno, como era el caso de Manuel Azaña.

De 1905 en adelante Ramiro de Maeztu residió, como se ha señalado, en Gran Bretaña y Alemania, desde donde enviaba colaboraciones a Nuevo Mundo y La Correspondencia de España. A partir del 10 de noviembre de 1909 dejó de publicar artículos en el segundo periódico y, a finales de 1910, compaginó los de Nuevo Mundo con los de Heraldo de Madrid, donde empezó a colaborar. El intelectual vitoriano se encontraba en Berlín cuando comenzaron las acciones de las potencias europeas en Marruecos, o sea, en la segunda mitad de mayo de

23 El Imparcial, 18 de septiembre, p. 3.

24 Heraldo Militar. Diario independiente de la tarde, 20 de agosto de 1911, p. 1. 
1911, en la que los franceses avanzaban sobre Fez, y el general Moinier entraba allí con sus tropas ${ }^{25}$.

Dos días después de que llegara la columna de dicho general a la capital religiosa del Imperio, esto es, el 23 de mayo, expresaba así de clara y rotunda en Heraldo de Madrid su reserva respecto a la República: "No cabe duda de que Francia tendrá que pagar en su día a Alemania el permiso tácito para el avance de sus tropas a Fez, como sugiere el Norddeustche Allgemeine Zeitung". A lo que añade que de esta opinión participan tanto la prensa liberal como la conservadora germanas y que, aunque la socialista discrepa, no tiene fuerza para influir en el Gobierno, cuando se trata de los intereses de Alemania ${ }^{26}$.

El publicista vitoriano fue enviado por el semanario Nuevo Mundo desde Alemania al Reino Unido con el fin de que informara acerca de la coronación de Jorge $\mathrm{V}$ en el mes de junio. En consecuencia, se encontró al margen de la ida de tropas españolas a Larache y Alcazarquivir el día 3 de ese mes y lo mismo de su desembarco en el continente cinco días después.

Vuelto a Berlín poco más tarde de la llegada a Agadir del cañonero germano Panther el 1 de julio, publicaba en Heraldo de Madrid del día 9 "La sombra de la Guerra", donde manifestaba que Alemania estaba viendo cómo otros países europeos y norteamericanos extendían sus dominios, mientras ella "con su industria, sus universidades, su ejército y su marina" también se arrogaba derechos coloniales, si bien era cierto que en esos momentos el coste económico de una posible empresa aconsejaba no acometerla ${ }^{27}$.

$\mathrm{Su}$ estancia en el Reino Unido durante el mes de junio y su posterior regreso a Alemania hubieron de influir en su observación y juicio de los acontecimientos de Marruecos desde un punto de vista británico y germánico.

Comenzadas las negociaciones entre Francia y Alemania para llegar a un acuerdo respecto al reparto de sus dominios en África, señala Maeztu que en Alemania se rumorea que ésta dejará a aquélla libre en el sultanato a cambio de Camerún y otros territorios y que España quizá quede excluida de las negociaciones. Por eso concluye así su artículo del 15 de julio "El plan de Alemania": "Pensemos los españoles estas cosas y pensémoslas bien, no sea que se nos utilice como instrumento y se nos abandone después de que se nos haya utilizado"28.

Si Ramiro de Maeztu se había mostrado hasta aquí muy crítico con Francia y benévolo con el país en que residía, a finales del mes de julio se declara abiertamente anglófilo en "El acuerdo francoalemán", pues en este artículo del 27 censura que en el concierto que se está gestando entre las dos grandes potencias se deje al margen a

25 En julio de ese año coincidió en Marburgo con José Ortega y Gasset, el cual le había conseguido una beca de la Junta de Ampliación de Estudios. Véase Pedro Carlos González Cuevas: Biografía de un nacionalista español, Madrid, Marcial Pons, 2003, p. 155.

26 La poca simpatía de Maeztu con Francia se había podido advertir en artículos anteriores firmados en Berlín; tales eran el datado el día 2 de mayo y publicado en Heraldo de Madrid el 5, p. 1, con el título "El aviso de Alemania" o el aparecido trece días más tarde rotulado "La comedia de Marruecos".

27 Heraldo de Madrid, 9 de julio de 1911, p. 1. Fechado el día 4 en Londres. El 13 publicaba en la página cuarta de Nuevo Mundo el artículo "Desde Londres. Agadir", colaboración que debió de escribirla en la capital inglesa antes de regresar a Alemania en los primeros días de Julio. Afirmaba en ella que la prensa londinense trataba con moderación y quitando tensión la llegada a Agadir del buque de guerra alemán, pero comentaba con amargura que el presidente Monis hubiera cedido a la presión colonial francesa para ir a Fez. Tal hecho, dice Maeztu, ha originado la pérdida de la amistad con Francia y ha supuesto una excusa para que Alemania prosiga su política de expansión "sin escandalizar a los socialistas ni a los intelectuales de ideas avanzadas".

28 Heraldo de Madrid, 15 de julio de 1911, p. 1. Fechado el día 11. 
los británicos. Ello se debe a la escasa consideración en que se tiene al Reino Unido, la cual sería mucho mayor si éste imitara a los germanos en la energía y en los trabajos físico e intelectual; y refiriéndose a la educación, añade: "Las universidades y colegios de segunda enseñanza [británicos] no sirven. Enseñan a los alumnos a ser corteses y a comportarse como gentlemens, pero no les enseñan a trabajar". El artículo lo cierran estas palabras: "El Reino Unido, en este estado de debilidad, aceptará con tristeza que Francia admita las propuestas de Alemania de apropiarse del Congo y Camerún"29. Con todo, piensa Maeztu que Gran Bretaña quizá se encuentra ahora con la respuesta de los alemanes a las negociaciones que mantuvo con Francia en 1904, en las que éstos quedaron excluidos ${ }^{30}$. La posible marginación del Reino Unido vuelve a situar a Maeztu frente a los franceses, pero sin estar de acuerdo con los alemanes. Así, en "La hegemonía alemana" manifiesta que Francia se halla cohibida y va cediendo frente a los germanos, a pesar de saber que, según él, cuenta con el apoyo incondicional de Gran Bretaña. Tal proceso en las negociaciones es un peligro para la estabilidad porque "dentro de un año, de dos años, de tres años, volverá a sentir Alemania otro deseo de expansión. Ya ha aprendido el camino. No necesitará sino enviar un barco a Agadir o a Casablanca" ${ }^{31}$. A finales de agosto y durante el mes de septiembre, en plenas negociaciones franco alemanas, se acumulan en la prensa numerosos artículos sobre la cuestión marroquí de Maeztu, Baroja, Ortega y Gasset y Manuel Azaña. Escritos normalmente discrepantes y cruzados entre ellos ${ }^{32}$.

Pero sigamos centrados en los artículos periodísticos de Ramiro de Maeztu. El 28 de agosto publica en Heraldo de Madrid "Desafrancesados", artículo en el que lanza un feroz ataque contra Francia, diciendo que ésta ha dejado de ser para España "la ventana del mundo". Los intelectuales españoles que hasta hacía poco tiempo leían y escribían en francés han vuelto su mirada hacia los libros en inglés y alemán, y no sólo a los de temas científicos, pues "el desencanto respecto a Francia se ha extendido rápidamente a nuestros literatos y aun a nuestros periodistas". El afrancesamiento espiritual en España acabó en el siglo XIX, el XX es ya de germanización y anglosajonización. Si nos llamábamos latinos, queríamos decir franceses; ahora, cuando se habla de europeos, vienen a la mente Alemania y El Reino Unido. El presente "desafrancesamiento" se debe a que el país vecino no evoluciona, pues, en él, unos miran al pasado y otros se resignan en el presente: Frente a esto, los españoles creemos en la posibilidad y en la necesidad de que "las cosas se renuevan al infinito".

29 Nuevo Mundo, 27 de julio de 1911, p. 4.

30 Nuevo Mundo, "El hecho de Marruecos", 3 de agosto, p. 3.

31 Nuevo Mundo, «La hegemonía alemana», 10 de agosto, p. 3.

32 Por orden cronológico se citan los siguientes: Ramiro de Maeztu "Desafrancesados", Heraldo de Madrid (H de M), 28 de agosto de 1911, p. 1; Pío Baroja “¿Con el latino o con el germano?”, El Imparcial (Imp), 31 de agosto, p. 1; Ramiro de Maeztu, "La Guinea y Fernando Poo", $H$ de M, 3 de septiembre, p. 1; Pío Baroja, "España, Alemania y Francia", Imp, 5 de septiembre, p. 1; Ramiro de Maeztu, "El error de Francia", $H$ de M, 6 de septiembre, p. 1; José Ortega y Gasset, "Alemán latín y griego", Imp, 10 de septiembre, p. 4; Martín Piñol (Manuel Azaña), "Las arriesgadas proposiciones de Pío Baroja”, La Correspondencia de España, 11 de septiembre, p. 1; Ramiro de Maeztu, "Francia y Alemania. Minas y contratas en Marruecos", H de M, 12 de septiembre, p. 1; José Ortega y Gasset, "Una respuesta a una pregunta I", Imp, 13 de septiembre, p. 4; Ramiro de Maeztu, "Francia y Alemania. Garantías y privilegios", H de M, 18 de septiembre, p. 1; José Ortega y Gasset, "Una respuesta a una pregunta II", Imp, 21 de septiembre, p. 4; Ramiro de Maeztu "La cultura esencial”, Nuevo Mundo, 21 de septiembre, p. 1; Pío Baroja "Europeización”, Imp, 28 de septiembre, p. 1; Ramiro de Maeztu, "El ejemplo de arriba", $H$ de $M, 28$ de septiembre, p. 1; Ramiro de Maeztu, "Italia, Trípoli, Turquía", $H$ de $M$, 30 de septiembre, p. 1. 
A pesar de que en lo social, científico y cultural Maeztu prefería a Alemania, en la política exterior se mostraba el 3 de septiembre tan antigermano como antifrancés. Y es que el periodista del Berliner Tageblatt Teodoro Wolff, reflejando la opinión de muchos alemanes, consideraba que España debía dejar Guinea y Fernando Poo, igual que la República tenía que ceder territorios de su influencia a favor del Imperio: "Ahora el radical Berliner Tageblatt imita la conducta de los pangermanistas". A lo que añade que, si bien la llegada del Panther a Agadir semejaba hacer respetar el poder alemán en Marruecos así como recordar a Francia el cumplimiento del Acta de Algeciras, resulta que también representaba el primer paso para intentar ampliar sus dominios en África, aspiración en que se han unido los liberales a los pangermanistas $^{33}$. De este modo, el citado diario alemán venía a coincidir con los periódicos hispanófobos franceses proponentes de que España debía sufrir las consecuencias de haber ido a Larache y Alcazarquivir.

Acudir a África para exhibir su poder y que se respetase su honor no era, por tanto, el fin último de los alemanes, sino conseguir un beneficio económico como señala Maeztu el día 12 de septiembre en "Francia y Alemania. Minas y contratas en Marruecos". Los germanos aspiraban a explotar los minerales y a conseguir las adjudicaciones de obras públicas del Imperio jerifeño o, en su defecto, a los beneficios del caucho, el café y el cacao del Congo ${ }^{34}$.

Para Ramiro de Maeztu, la actitud del Reino Unido en este debate de intereses entre Francia y Alemania era la de atento observador, a pesar de que se sintiera satisfecho con la total libertad de que disfrutaba para actuar en Egipto, pues veía con recelo que Francia pudiera quedar como única potencia monopolizadora de Marrue$\cos ^{35}$, lo cual dejaba en evidencia que la República no contaba en estos momentos con el apoyo incondicional de Gran Bretaña.

Estos vaivenes del Reino Unido a favor de unos u otros según sus conveniencias no cesaban. En efecto, ahora animaba a Italia a lanzarse sobre Trípoli, con lo que obligaba a Alemania a tener que decidirse por su amiga Turquía o por su aliada Italia ${ }^{36}$.

A finales de octubre se presentía la firma del acuerdo entre Francia y Alemania. En ese contexto, R. de Maeztu tomó la pluma para escribir contra el expansionismo actual de Italia, pero también contra el imperialismo en general, pues los italianos habían hecho lo mismo que los alemanes en Marruecos o los ingleses en todo el mundo. Por otro lado, el articulista apelaba a que finalizara la rivalidad entre el Reino Unido y Alemania, porque el enfrentamiento facilitaba las ocupaciones coloniales suyas y las de otros países ${ }^{37}$.

De regreso a Londres, tras medio año en Alemania, publica Maeztu el 30 de octubre en Heraldo de Madrid "Proteccionismo". En línea con su pensamiento sobre Francia, la califica de "proteccionista por excelencia" en todo: las relaciones comer-

33 "La Guinea y Fernando Poo", Heraldo de Madrid, 3 de septiembre de 1911. Fechado en Berlín el 31 de agosto.

34 Heraldo de Madrid, 12 de septiembre, p. 1. Berlín, 9 de septiembre.

35 "Francia y Alemania. Garantías y privilegios", Heraldo de Madrid, 18 de septiembre de 1911, p. 1. Berlín, 13.

36 Véase Ramiro de Maeztu, "Italia, Trípoli, Turquía”, Heraldo de Madrid, 30 de septiembre de 1911. Berlín 26. En el artículo "El Sultán de Prusia»" Heraldo de Madrid, 3 de octubre, p. 1 (Berlín 28 de septiembre), insiste en el apoyo de Gran Bretaña a Italia en la cuestión de Trípoli. Además, se refiere a cómo Alemania y Rusia habían firmado semanas atrás un acuerdo para que la segunda pudiera actuar libremente en Persia, por lo que Alemania se veía en la obligación de afianzar sus aspiraciones en Marruecos.

37 "Un principio de acuerdo", Nuevo Mundo, 26 de octubre, p. 4. En el mismo sentido se manifiesta en "La Entente Cordiale", Nuevo Mundo, 2 de noviembre, p. 4, donde afirma que se alegra de que desaparezca esa alianza en beneficio de otra anglo-alemana, apoyada por el partido liberal inglés. 
ciales, la lengua e incluso lo demográfico, con su control de natalidad, que puede significar el "suicidio de su raza". Además, los franceses son tratados en su nación como si fueran niños. El liberalismo de países como Gran Bretaña no existe en la Republica. Y concluye: "Pregunto a los españoles jóvenes, anhelosos de buscar el camino por el que llegue nuestra patria a vías de expansión y de vitalidad germinadora: ¿Puede enseñarnos Francia otra lección sino la de las cosas que no deben hacerse?"38.

Resumiendo todo lo expuesto en el examen de de los artículos publicados por Ramiro de Maeztu desde mayo hasta noviembre en que se refiere a la cuestión marroquí relacionada con las potencias europeas, puede decirse que en el terreno cultural se manifestó simpatizante con el Reino Unido y Alemania, frente a lo francés, y, en cuanto a la política, a favor, aunque con alguna reserva, de Gran Bretaña y España, y contrario al expansionismo galo, germano e italiano. En conclusión, su antipatía hacia Francia no dejaba lugar a dudas.

\section{Pío Baroja}

Antes de adentrarnos en los artículos publicados por Pío Baroja en 1911 relacionados con Marruecos y Francia, no sobrará recordar su buen conocimiento de la cultura, la sociedad, el pensamiento, la política, etc., del país vecino a través de sus lecturas, pero también, y principalmente, de sus reiteradas estancias en París desde $1899^{39}$. Además, se había informado bien de la política exterior francesa durante su misión en Tánger como corresponsal del diario El Globo a finales de 1902 y en enero de 1903, cuando era ministro de Asuntos Extranjeros de la República el colonialista Delcassé, quien había firmado en el primer año citado un tratado con el Reino Unido poco favorable para España. Este período de casi un mes en Marruecos le sirvió de inspiración para escribir al menos parte de la novela Paradox, rey (1906), en la que se critica sin ambages la colonización europea, en especial la francesa, so pretexto de culturizar a los pueblos "salvajes" 40 .

Pero es que, además, Baroja se encontraba en París en vísperas de la acción del ejército galo en Fez, en abril y mayo de 1911. Allí hubo de enterarse de las opiniones y deseos, sino de todos los franceses, sí de los de los periódicos más significados a favor de dicha intervención como Le Temps y Le Matin. Este último publicaba en su primera página del día 5 del segundo mes el artículo "Nos Troups en Maroc" en el que criticaba los recelos de algunos diarios españoles y alemanes de que "le but poursuvi par la France est la conquête du Maroc", y agregaba, ya al final, que esos rotativos del sur de los Pirineos olvidaban que Francia, por un tratado solemne, estaba encargada de mantener el orden y la paz en Marruecos gravemente alterados en

38 Heraldo de Madrid, 30 de octubre de 1911, p. 1. Fechado en Berlín el 28.

39 Ya en el primer artículo de la serie "Desde París", La Voz de Guipúzcoa del 20 de julio de 1899, p. 1, deja clara su visión poco positiva de Francia.

40 He aquí el comportamiento del ejército francés en la capital del reino de Uganga: "Está anocheciendo. Bu-Tata entera arde por los cuatro costados. Los cañones franceses han lanzado una lluvia de granadas de melinita, que han incendiado casas, almacenes chozas, todo [...]. Como si hubiera habido un terremoto, Bu-Tata se ha desmoronado [...]. En la escuela, que, por una casualidad no se ha venido abajo, está reunido el Estado Mayor francés, y sobre el tejado de este edificio ondea la bandera tricolor", Pío Baroja: Paradox, rey, Madrid, Caro Raggio, 1973, p. 304. Bu-Tata, era un territorio bereber localizado en el sur del Marruecos actual, al que los españoles consideraron un reino en el siglo XV. 
esos momentos: "Notre seul but, que nous sommes fermement décidés à atteindre, c'est rétablir et maintenir l'ordre dans le pays"

La fundamentada escasa simpatía de Pío Baroja con la política de Francia relacionada con España en África, e igualmente con ciertos aspectos de su sociedad y cultura, la mantuvo durante toda su vida, lo que no le impidió reconocer al país transpirenaico méritos como el de las novelas surgidas de las plumas de Balzac, Stendhal o Merimée.

El principal novelista de la generación del "98" se introduce en la controversia mantenida en los periódicos acerca de qué lado debía situarse España a propósito de los acontecimientos de Marruecos del año 1911 con la publicación en la página primera de El Imparcial del 31 de agosto de "¿Con el latino o con el germano?”. Eran los días en que comenzaban las negociaciones entre Francia y Alemania para cerrar un acuerdo sobre el reparto de territorios y asuntos comerciales, tras la llegada del cañonero Panther a Agadir.

Cinco fueron las colaboraciones del escritor guipuzcoano en El Imparcial desde la citada inclusive hasta que el 4 de noviembre se firmara el aludido convenio entre alemanes y franceses: "España, Alemania y Francia" (5 de septiembre), "Europeización" (28 del mismo mes), "La cuestión de Marruecos (por uno de la calle)" (23 de octubre $)^{42}$ y "Examen de criterios" (30 del mismo mes) $)^{43}$.

El Imparcial, diario en el que colaboró con cierta frecuencia Baroja desde 1901, reaccionó contra la actuación francesa en Fez el 21 de mayo de ese año, cuando la prensa de Francia comenzó a oponerse a la ida de España a Marruecos, aunque hubiera protegidos españoles que estaban sufriendo problemas en Larache y Alcazarquivir. Así queda probado en el editorial del 2 de junio en el que se dice que el general Moinier, jefe militar que dirigía las tropas francesas que entraron en Fez, era quien mandaba en el Imperio jerifeño, tras la petición de ayuda del Sultán a Francia; o sea, Marruecos se había convertido de hecho en un protectorado francés ${ }^{44}$. El

41 Cuenta Pío Baroja en Final del siglo XIX y principios del XX, Madrid, Caro Raggio, 1982, pp. 387 y ss., que encontrándose en 1911 en París, para no aburrirse, comenzó a escribir El árbol de la ciencia (se publicaría en diciembre). La prueba de que Baroja estuvo en la capital de Francia hasta casi mediados de 1911 la aporta él mismo, cuando señala que Rubén Darío lo invitó a escribir en una revista que iba a crear titulada Mundial Magazine, en la que no llegó a colaborar. El primer número se publicó el día 5 de dichos mes y año.

42 Los artículos de Baroja aparecieron siempre en la primera página del periódico. "La cuestión de Marruecos (por uno de la calle)" no se había recuperado hasta 2014, en Corresponsalía de guerra y otros textos olvidados, Madrid, Car Raggio, pp. 164-169.

43 Pío Baroja seguiría escribiendo sobre sus simpatías o antipatías respecto a Alemania y Francia en los años siguientes de esta década en El Imparcial, la revista España, ABC y El Día. Entre sus artículos de los mencionados diarios, citamos el inserto en el primero con el título de "Las alianzas. La cuestión espiritual" (El Imparcial, 13 de mayo de 1913), porque no había sido recuperado hasta Corresponsalía... 2014, pp. 173-178. Baroja continuó con sus manifestaciones de desafecto respecto a Francia a lo largo de su vida. Todavía en la segunda década del siglo pasado el libro Las horas solitarias, publicado en 1918, antes de acabar la Primera Guerra Mundial, se hallaba salpicado de críticas hacia el país vecino como ésta: "Para mí, el militarismo francés y el alemán son por el estilo. Yo siento por los dos el mismo asco; ahora el francés me parece aún más grosero [...]. Siento por los franceses, alemanes e ingleses cada vez menos simpatía y un deseo mayor de no enterarme de lo que hacen", Madrid, Caro Raggio, 1982, pp. 78-79. Otros reproches a Francia pueden leerse en las pp. 22, $72-73$ y 201. El círculo de censuras al país transpirenaico puede darse por cerrado con lo que manifiesta en su tercer libro de "memorias": Final del siglo XIX..., pp. 98-100: "Yo, siendo un gran admirador de Francia, siempre he sospechado que los franceses tienen un fondo de incomprensión para todo lo extranjero [...]. A mí muchos me han atribuido la condición de ser galófobo. No creo que sea cierto. Yo no soy galófobo sino todo lo contrario. Lo que creo es que no basta que una obra literaria, científica o artística salga de París para que sea una gran cosa".

44 En honor de la verdad hay que decir que El Imparcial ya había criticado el comportamiento del Gobierno galo, el cual manifestaba su respeto al Acta de Algeciras, mientras movilizaba tropas por y hacia distintos territorios 
grado de enfrentamiento entre los periódicos Le Temps y El Imparcial va creciendo, al publicar aquél, el día 4, "L'Espagne au Maroc", con ocasión de los rumores de una acción española en sus zonas de influencia de Jebel, Darsa o Tetuán. Además de oponerse a una eventual intervención española, el diario francés acusaba al español y al hijo de su fundador, el ministro Rafael Gasset, de ser uno de los instigadores de que España acudiera a Marruecos en auxilio de sus protegidos: "Mr. Gasset, ministre de Travaux publics du cabinet Canalejas, est vraisemblablement l'âme de cette galophobie mesquine, dont chaque jour nous apporte un nouveau témoignage". $E l$ Imparcial contestó el día siguiente y, con mayor extensión el día 6 , después de haber leído detenidamente el artículo publicado el 4 por el rotativo galo. El periódico español lanzaba contra el francés una implacable crítica en dos columnas y media, la cual comenzaba diciendo que "forzosamente habremos de reconocer que la acritud y la insidia [de Le Temps] son mucho mayores de lo que presumíamos [...]. La lectura del artículo nos ha proporcionado, aparte la desagradable sorpresa de su sentido general, la de encontrarnos directamente aludidos, no sólo en nuestra actual obra periodística, sino en la ilustre y venerada memoria del fundador de El Imparcial". La despiadada polémica entre los dos periódicos seguiría subiendo de tono en días posteriores.

Así, el día 8, Le Temps publicaba el editorial "La France et l'Espagne au Maroc" en el que empezaba aseverando que sus páginas llevaban tres día ocupándose del mal humor de la prensa de Madrid y quería poner los puntos sobre las íes. Uno de esos puntos era que Heraldo de Madrid, Diario Universal y El Imparcial estaban incitando a España a apoderarse de territorios en Marruecos, a lo que respondió el último rotativo citado acusándolo de abusar de su condición de órgano oficioso del Ministerio de Asuntos Exteriores "para dar mayor importancia a animosidades y opiniones que acaso profesan solamente sus redactores y algunos miembros exaltados del partido imperialista". Dos jornadas después, en "Le Temps y la prensa Española. Los puntos sobre las íes" el periódico español analizaba el artículo del francés del día 8 y acusaba a éste de «agresividad gratuita» y "lenguaje poco amistoso".

La controversia entre El Imparcial y el diario francés alcanzó un grado más de acritud con la llegada del cañonero Panther a Agadir el 1 de julio, puesto que Le Temps imputaba a España haber concertado con Alemania dicha acción o, al menos, congratularse de que los germanos hubieran realizado tal manifestación de fuerza frente a su vecino del suroeste.

Pero volvamos a la reacción del diario oficioso del Quai d'Orsay ante la llegada a Marruecos del ejército de España a comienzos de junio. Tanto ese rotativo como la mayoría de los medios galos coincidían en que los territorios de influencia española no atravesaban circunstancias que requirieran la intervención militar, a lo cual respondió El Imparcial el 11 de junio en sus dos primeras páginas:

Ha podido Francia llegar hasta Fez y establecer un protectorado de hecho, convirtiéndose en beligerante y mezclándose a las eternas contiendas civiles del Imperio, sin más que establecer la verdad convencional de que sus nacionales corrían gravísimos peligros. ¿No podrá España acudir en auxilio de sus compatriotas cuando ruedan por el suelo cabezas de sus protegidos y la paz es de tal naturaleza en

del sultanato. 
Alcazarquivir que llegan hasta doscientos los jinetes montañeses poniendo temor y angustia en los corazones de extranjeros e indígenas?

Añade el periódico que el Gobierno francés da crédito a los que afirman que en la zona de influencia española se respira tranquilidad y que, en caso de que no la hubiera, se lograría mediante la actuación del Raisuli. El principal medio al que creía el Gobierno, o quizá utilizaba, para difundir que Larache y Alcázar no vivían momentos inquietantes era Le Temps. Este «indignado y vocinglero» periódico, según El Imparcial, solicitaba, además, que se rompiera el acuerdo franco español y que se denunciara a las potencias el incalificable proceder de España.

He aquí el tenor del debate entre los dos periódicos hasta la estampación el último día del mes de agosto del artículo de Pío Baroja “¿Con el latino o con el germano?”. Pero antes de analizar esta colaboración del escritor vasco en El Imparcial, procede detenerse en lo publicado los días 29 y 30 en los periódicos a que nos estamos refiriendo.

Le Temps ofrece el primer día citado, en sus dos primeras páginas, «À propos des relations franco-espagnoles», con la firma de Auguste Bréal. El autor aboga por un mejor conocimiento mutuo para conseguir mejores relaciones entre los dos países y cierra su artículo con estas palabras:

Le jour où les Français de plus en plus nombreux auront sentir le plaisir de frayer avec un peuple dont seulement les qualités, mais jusqu'aux défaits, concordent avec les nôtres, ce jour-là il faut espérer que les Espagnols aussi nous connaitrons mieux. Alors, si sensible que soit l'épiderme de deux peuples, si ombrageux yeux que puisse être le pundonor, il y aura entre Français et Espagnol une sympathie profonde, la conscience d'une communauté de culture, de sentiments, d'idéal; et les plus habiles fauteurs de querelles, les politiques les plus accoutumés à troubler l'eau avant d'aller à la pêche y perdront leur latin. Entre Français et Espagnol, il ne saurait y avoir que de simples malentendus, Il faut apprendre à s'entendre, à s'entendre directement, sans interprète.

Ese intérprete, según se deduce del texto de Bréal, es la prensa envenenadora de las relaciones con Francia. En realidad, el artículo encierra una interesada apelación a España para que, en los momentos de negociación entre galos y germanos, ésta no se alíe con los segundos sino con los primeros.

Tras hacerse eco del artículo de Le Temps, El Imparcial de ese mismo día manifiesta, que aunque aparente una llamada a la unión franco española, se trata de una argucia, para contar con el apoyo de España en un momento conflictivo entre Francia y Alemania. Con todo, es el día 30 cuando el periódico español responde con mayor contundencia al escrito de A. Bréal con otro titulado «El artículo de Le Temps. $\mathrm{La}$ hermandad latina». Editorial este de El Imparcial que parece haber sido escrito por Pío Baroja, si se le compara en cuanto al contenido, expresión y ubicación en la primera página del periódico con la colaboración del novelista vasco del día siguiente en dicho medio ${ }^{45}$.

Redactara o no Pío Baroja el reiterado editorial, lo cierto es que se sintió identificado con las ideas que respecto a Francia venía manteniendo El Imparcial en los

45 Igualmente, presenta una gran semejanza con "España, Alemania y Francia”, también de Pío Baroja. 
tres meses últimos. En coincidencia con ellas, escribió el artículo publicado en el 31 de agosto. El autor de "¿Con el latino o con el germano?” niega la existencia de una comunidad latina porque Francia, España, Italia y Portugal no participan de características comunes o son muchas las que las diferencian. En consecuencia, cada país se relaciona con aquél que más le conviene. A España le interesa, aunque parezca difícil, inclinarse del lado de Alemania y no hacia la vecina del norte, pues la "alianzas con Francia e Inglaterra han dado históricamente a España mal resultado". Por el contrario, "en Italia, en Francia, en Suiza, en Bélgica, en Holanda, las zonas fronterizas más germanizadas son las más prósperas. Nosotros no tenemos, por desgracia, ninguna frontera con Alemania; si la tuviéramos, la influencia alemana se ejercería aquí de una manera natural, sin necesidad de alianzas". Pero, si hubiera que coligarse con algún país:

La alianza política hecha por los gobiernos de España y Alemania, como la desean los reaccionarios, podrá traernos solamente la parte exterior de la Alemania actual, la parte de postura y baladronada del Kaiser, la parte de la Alemania del cuartel y de cuerpo de guardia, y no la Alemania científica, organizada e industrial, que es la que nosotros queremos conocer e imitar. En este caso, la alianza más conveniente, sería perjudicial.

En conclusión, según Baroja, la relación más provechosa que puede alcanzar España es con Alemania.

El artículo siguiente de Pío Baroja en estos días, siempre en El Imparcial, se publica el 5 de septiembre y lleva por título "España, Alemania y Francia". Se trata de la contestación a una carta de "Un francés que amaba a España" el cual había respondido a su artículo anterior. Replica Baroja al remitente de la carta diciendo que en cuestión de pensamiento e inventos los franceses van siempre por detrás de los alemanes, aunque luego se beneficien de ellos. No niega la primera línea de Francia en cuanto a la ciencia, pero lo que no admite es que los franceses se consideren los primeros y únicos en todo. Así, a los españoles que ostentan el mérito de ser inigualables en las artes, lo único en que han sobresalido, los tienen por imitadores de franceses:

Francia ha llamado a Velázquez el Lebrun (sic) español; a Murillo el Lesueur español; a Goya el Daumier español [...]. Ya estamos avisados: ya queremos enterarnos, con los medios pequeños de un país pobre; ya queremos ver con nuestros ojos y oír con nuestros oídos. Ya no nos darán un Cousin por un Kant, ni un Saint-Saens por un Wagner, ni un Delacroix por un Goya, ni un Mauricio Barrés, por Nietzsche. Vamos a hacer nuestra clasificación; mal, probablemente imperfecta, pero nuestra. Por eso queremos a Alemania: para que nos ayude a desafrancesarnos.

(Recuérdese que Ramiro de Maeztu había publicado el 28 de agosto en Heraldo de Madrid un artículo titulado "Desafrancesados").

La colaboración posterior de Pío Baroja que se estampó en El Imparcial el día 28 del noveno mes bajo el marbete de "Europeización" no se refiere directa ni indirectamente a Francia. El artículo trata de que en España existen dos corrientes de pensamiento: la tradicional, que sostiene que aquí no se necesita nada del exterior, y la de los europeizadores sin ningún límite. Para Baroja, lo acertado es abrirse a Europa 
en lo científico y filosófico, mientras que en lo artístico, lo literario y lo moral cada pueblo es distinto y alberga su propia sensibilidad.

El lunes 23 de octubre vuelve Pío Baroja a tratar del colonialismo en África en su artículo "La cuestión de Marruecos (por uno de la calle)". Aquí regresa el autor a ocuparse de la existencia de dos grupos de opinión en España, pero ahora referida a la actuación española en el norte de África. Hay gentes que consideran que se debe ir a Marruecos a modo de continuación de la Reconquista o como medio de desarrollo de la industria y la minería españolas. Aducen, además, que si no lo lleva a cabo España, ésta quedaría rodeada por Francia. En contra de tal criterio se muestran en especial los socialistas, quienes alegan que los moros se bastan a sí mismos para administrar y pacificar su territorio. Añaden también que en España "hay muchos campos que cultivar muchas minas que explotar, muchos pantanos y puentes que construir". El autor propone, como cualquier "hombre de la calle", que, cuando lleguen las negociaciones hispano francesas, Francia, "que no ha comprendido nunca a España, que no comprende ahora su situación, la va a tratar posiblemente como a una rival odiada, hiriéndola inútilmente", ayude a ésta económica y militarmente en el control de su territorio de influencia, pero si le exige abandonar Larache y Alcacazarquivir debería retirarse de todo Marruecos, a cambio de alguna compensación. Quedarse solo con el Rif sería una calamidad pues los soldados españoles tendrían que "empapar de sangre una tierra maldita y estéril". En conclusión: "En las circunstancias que se avecinan para España, quizá el más imprudente fuera el más prudente; el que dijera: 'O todo o nada' estaría en lo cierto. En las soluciones mixtas es donde se halla seguramente el mayor peligro".

En el artículo del penúltimo día de octubre ${ }^{46}$ "Examen de criterios" reitera Baroja dos ideas del anterior: La presencia en España de un sector de la población partidario de la acción del ejército en África, compuesto en su mayoría por militares, periódicos reaccionarios y articulistas como el doctor Maestre, y de otro sector contrario a éste, en cuyo extremo se sitúan los socialistas. La segunda idea, expuesta al final, se refiere a lo que habría que hacer en las negociaciones con Francia:

España debe ir a la negociación con criterio utilitario puro, sin mezcla de tropos retóricos ni de palabrería de juegos florales.

No hay nada feo ni deshonroso en esto. Francia y Alemania han chalaneado como los cañís de la Puerta de Toledo.

Nosotros, más pequeños, podemos negociar también sin menoscabo de dignidad.

Tenemos una cosa cotizable. ¿Hay que cambiar? Cambiémosla por algo bueno. ¿Hay que vender? Vendámosla lo más cara posible.

España debe examinar todas las soluciones y todas las posibilidades. Entre dos comerciantes que pactan, el que intenta hacer intervenir la caballerosidad y el honor en sus diferencias no prueba que es un hidalgo, sino un imbécil.

De cualquier modo, hay que reconocer que Pío Baroja había relajado en sus últimos artículos de El Imparcial el tono de su animadversión contra Francia, pero el 5 de enero de 1912, firmado ya el convenio entre este país y Alemania el día 4 de noviembre, dicho periódico publicó una nueva colaboración de Baroja cuyo título no

46 El Imparcial, 30 de octubre de 1911, p. 1. 
podía ser más significativo: "Nuestra francofobia, nuestro españolismo". El artículo de Baroja respondía a otro de Le Temps enviado desde Madrid el 28 de diciembre del año anterior y firmado por J. F. Juge, el cual publicaba el diario francés cuatro días atrás. El autor de "L'amitié espagnole" acusaba a España de atribuir sus males pasados bien a los jesuitas, bien a los ingleses, bien a la anarquía. Ahora, salvo para El País, El Diario Universal, La Correspondencia de España, rotativos como La Mañana, La Época, Heraldo de Madrid, ABC, El Imparcial e incluso El Liberal «semblent avoir fait du francophobisme leur unique raison d'existence». A lo que agrega en los dos último párrafos:

Voici, par exemple El Imparcial qui dressa, au cours de l'été dernier, une sorte de bilan intellectuel de la France. Le rédacteur, un romancier connu, Pío Baroja, estima que tout bien considéré nous ne valions par grand'chose (sic). Nos poètes étaient médiocres, nos philosophes sans profondeur, nos inventeurs sans génie. Que doit-on à la France? Se demandait en terminant Baroja. Je n'aurai pas la cruauté de lui répondre et je me contenterai de lui rappeler qu'il y eut au dixhuitième siècle un nommé Masson qui posa une question du même genre.

Ne croyez pas que ce romancier soit seul de son opinion. Il y a un certain nombre d'écrivains et d'universitaires que se sont acquis, grâce au galophobisme, une manière de réputation dont ils continueront à jouir tant que leurs compatriotes ne chercheront point l'origine du savoir dont ils font étalage.

El aludido escritor vasco protestó enérgicamente contra las acusaciones a la generalidad de la prensa española, al diario en que colaboraba y a su propia persona. Comenzaba admitiendo que en algunos periódicos madrileños podía darse la francofobia, al igual que la hispanofobia en otros de París, pero no aceptaba que al sur de los Pirineos se tuviera inquina al país vecino sino al contrario, pues "durante muchos años la vida española ha sido una copia de la francesa en ideas, en nombres, en todo [...]. Es verdad que en España comienza a aparecer cierta tendencia antifrancesa, pero esa tendencia, hoy por hoy, es ligerísima". Los españoles no desprecian a Francia, según Baroja; la consideran quizá la principal nación del mundo, pero “creemos también que no ha fecundado a España, que no la ha servido, que no la ha ayudado. ¿Es culpa suya o nuestra? Yo creo que es culpa suya”. Si fuera la falta de los hispanos, lo sería por las dificultades de progresar con las ideas francesas y, por tanto, habría que ir a buscarlas en el Reino Unido o en Alemania: «La tendencia francófila y latina ha fracasado aquí». Continúa diciendo Baroja que, sin pretenderlo o a sabiendas, Francia siempre ha aconsejado mal a España:

No ha sido un español sino un político francés de importancia, Jaurés, el que ha dado a entender últimamente que Francia nos ha empujado a la campaña de Meli1la. Supongamos que no nos empujó, que dio únicamente su consejo, su permiso. Realmente no debemos agradecerle el favor. Gracias a ese permiso llevamos una campaña de miles de soldados muertos y cientos de millones de pesetas perdidos. En cambio, en Alcázar y Larache, Francia no solo no nos dio su visto bueno, sino que se opuso, y se ocuparon estas dos últimas ciudades a disgusto del Gobierno francés, sin disparar un solo tiro y sin matar a un solo hombre. 
El autor del artículo termina diciendo que, a las enumeradas, se podían añadir otras razones para justificar la antipatía de los españoles hacia el país vecino; o sea, para hacerse "más francófobos, mientras Francia sea, como hasta ahora, para los españoles, el país que no nos comprende, que no nos entiende, que nos pinta como una cosa absurda y arqueológica; el país que nos da el consejo del enemigo, en vez de la indicación del amigo".

No fue sino pasado un año cuando Pío Baroja volvió a publicar algún artículo en El Imparcial; es decir, hasta el 20 de enero de 1913, al estamparse en él "Nuestras energías (Preocupaciones de principio de año)". Meses después, el 13 de mayo, aparecería "Las alianzas. La cuestión espiritual" ${ }^{37}$. En estas colaboraciones periodísticas y en las que siguieron hasta terminar la Primera Guerra Mundial el novelista vasco aumentó la misma disposición respecto a Francia, afianzando aún más su interés por Alemenia, pero disconforme con el acrecentamiento de su organización e industria militares y el expansionismo imperial.

Varios han sido los estudiosos que se han detenido en examinar el poco afecto del escritor español hacia el país transpirenaico. Jacques de Bruyne y Jacqueline van Praag-Chantraine consideran, con opiniones extremas y, en algún aspecto, mal fundamentadas, que la antipatía de Baroja con Francia se debe a un complejo de inferioridad respecto a lo francés, al odio a lo extranjero, a su misantropía y a su oposición a todo; aunque, según ellos, estas peculiaridades quizá no son exclusivas de don Pío sino de todo el grupo del " 98 " 48 .

Por su parte, José Corrales Egea asevera que su "aparente galofobia [...] responde a una necesidad interior de defensa", porque, sintiéndose muy impregnado de la cultura gala, aspiraba a defender su autonomía. Para el autor de Baroja y Francia, don Pío sostenía el criterio de que cada cual debía estar en su sitio ${ }^{49}$.

En nuestra opinión, no hay por qué buscar justificaciones exculpatorias de la opinión de Baroja respecto a muchos aspectos de la nación francesa. Sus críticas a Francia existieron ya antes de esa supuesta impregnación a la que se refiere Corrales Egea y fueron haciéndose cada vez más severas, con algunos breves paréntesis. No resulta aventurado deducir que la escasa simpatía del escritor vasco por la Francia contemporánea y el aprecio que merecía ésta a personas por las que él tenía muy poca simpatía fueran la causa de su cada vez mayor inclinación hacia la Alemania científica, cultural, industrial, etc. De este modo llegó a declarase "germanófilo" en un artículo de octubre de 1914, sin prever que este adjetivo, al que muchos atribuyeron con mala fe el significado de germanómano, le iba a ocasionar innumerables ataques durante la Gran Guerra y después ${ }^{50}$.

Un año antes de concluir el conflicto publicaba Pío Baroja Juventud, egolatría, breve recorrido autobiográfico, en el que declaraba su adhesión en el terreno de la cultura a las opiniones de José Ortega y Gasset, coincidentes en gran parte a las que mantenía él respecto al mundo cultural y científico alemán: "[Ortega y Gasset] es

47 Estos artículos de Pío Baroja se estamparon en la página tercera. "Las alianzas. La cuestión espiritual” no se había recuperado del periódico, ya se ha dicho, hasta Corresponsalía de Guerra, pp. 173-178.

48 «Pío Baroja et les Français », Revue belge de philologie et d’histoire, Année 1969, 47,3. pp. 922.

49 José Corrales Egea: Baroja y Francia, Madrid, Taurus, 1969, 284.

50 «De un germanófilo a un suizo alemán», El Imparcial, 21 de octubre de 1914. La Primera Guerra Mundial había comenzado el 28 de julio. Sobre la atracción del escritor donostiarra por la Alemania cultural y científica, no la imperialista y expansionista, véase Miguel Ángel García de Juan: "Pío Baroja y su germanofilia en la conflictiva segunda década del siglo XX", Revista de Literatura, 154, julio-diciembre, 1915, pp. 399-422. 
para mí el viajero que ha hecho el viaje por las tierras de la cultura. Es un escalón más alto al que es difícil llegar [...]; es el maestro que trae nuevas aquí desconocidas. [...] Ortega y Gasset, única posibilidad de maestro que he conocido, es para mí de los pocos españoles a quienes escucho con interés" ${ }^{21}$.

\section{José Ortega y Gasset}

Pues bien, José Ortega y Gasset había obtenido en noviembre de 1910 la cátedra de metafísica de la Universidad Central y en 1911 fue a Marburgo, disfrutando de una beca de la Junta de Ampliación de Estudios ${ }^{52}$. En esta ciudad alemana permaneció un año, en cuyo mes de mayo nació su primer hijo ${ }^{53}$.

Varios españoles acudieron a Alemania en las primeras décadas del siglo XX por distintos motivos: ampliar estudios, ejercer de corresponsales... En ese mismo año 1911, María y Ramiro de Maeztu, con el fin de estudiar el neokantismo en el mismo Marburg; Luis Araquitain en Berlín, como corresponsal de El Liberal; Ramón Pérez de Ayala en Munich, con el propósito de seguir cursos de arte impartidos por Wöefflin. En 1909, también había estado en Berlín disfrutando de una beca igualmente de la JAE Fernando de los Ríos.

No pocos fueron, pues, los españoles que se sintieron atraídos en estas fechas por la cultura y ciencia germanas, lo que no se contradice con que otros como Antonio Machado o Manuel Azaña sintieran interés y se decidieran por ir a Francia.

Quien sería, pasado un tiempo, el mayor filósofo que ha dado España, publicó su primer artículo en El Imparcial, en el año 1911, el día 1 de enero, con el título "Al margen del libro. Vejamen del orador" ${ }^{54}$. El número de los firmados por él en ese año alcanzará casi la veintena, pero los que interesa examinar en este trabajo son los estampados en dicho diario entre mayo y diciembre y los aparecidos en ese tiempo en el periódico argentino La Prensa; o sea, aquellos relacionados con los acontecimientos de Marruecos.

El 31 de mayo pudo leerse en la tercera página de El Imparcial "Libros de andar y ver", con el largo subtítulo "Utopías geográficas. La ignorancia del Rif. Melilla como posibilidad. Los bereberes en el Rin. Et-Turqui y su comandante". Se trata de un artículo crítico con Francia y España, en el que se reprocha a ésta que no haya aprovechado la oportunidad de haber europeizado los territorios de su influencia en Marruecos. Por lo que respecta a la primera, discrepa de Otto C. Artbauer, quien, en su libro Die Rif Piraten un ihre Heimat, califica a Francia de hipócrita y de querer dominar el sultanato, a fin de conseguir soldados indígenas en mayor número aún de los que habían aportado Túnez y Argelia. Por otra parte, señala Ortega y Gasset que el autor austriaco defiende los derechos de España sobre ciertos territorios marroquíes.

51 Pío Baroja 1985, 28 y 29.

52 La beca se le concedió en diciembre del año anterior, a la vez que a Antonio Machado, entre otros, para ir a París. Ver La Correspondencia de España del 18 de diciembre de 1910, p. 4.

53 Ortega y Gasset ya había residido en Marburg en la década anterior, al igual que Leipzig y Berlín. Para conocer más datos de la estancia en aquella ciudad en 1911, véase Jordi Gracia: José Ortega y Gasset, Madrid, Marcial Pons, 2014, pp. 127-130.

54 Ortega y Gasset había comenzado a publicar en este diario propiedad de la familia, pues era nieto de su fundador, en 1904. La colaboración se extendió hasta 1917. Así lo registra Ignacio Blanco Alfonso: "El periodismo en la obra de Ortega y Gasset, en el centenario de su muerte”, Doxa Comunicación, nº4, 2006, pp. 13-36. 
En "Libros de andar y ver. Una descripción de la política internacional" su autor mantiene el mes siguiente la esperanza de que España cumpla con su destino, pues "nunca es tarde para nada con tal de que se tomen las tareas en la forma y el cariz a que el tiempo las ha traído y nos las pone por delante", y apela a los políticos españoles, con la exclusión de los ministerios de la guerra y marina, a que "fomenten una acción difusa del pueblo español sobre el pueblo del litoral marroquí". Una acción, aunque modesta, dadas las circunstancias por las que atraviesa España, que, "aprovechando la pendiente favorable de nuestra proximidad y de nuestra tradicional convivencia y aun semejanza, penetre en la psicología de la sociedad bereber algo de la estructura española". Esto sería muy beneficioso para España y para Marruecos, pues impediría que Francia dominara todo el Imperio, como no ha conseguido colonizar la totalidad de Argelia, Túnez, Madagascar y Nueva Caledonia ${ }^{55}$.

El 9 de julio publica La Prensa de Buenos Aires su artículo "El problema de Marruecos" dividido en cuatro apartados. El primero es, en gran medida, la reproducción de lo ofrecido en El Imparcial del 31 de mayo, con una mayor carga crítica del antigalicismo del libro de Artbauer. El segundo trata del desorganizado poder en Marruecos por culpa de Muley Hafid y su Gobierno. El tercero se refiere a cómo en el norte, junto a la supuesta potestad política del sultán se halla la autoridad religiosa del Jerife de Wasan, que aglutina a los musulmanes de la zona, los cuales permanecen fieles a Hafid. El jerife es, además, un fiel servidor de los consejos franceses. Pero enfrente se encuentra el jerif e del sur, el cual odia a Francia, aunque colabore con el sultán en el mantenimiento de de una "sombra de soberanía". En el último apartado expone Ortega y Gasset que las potencias europeas deben considerar este aspecto religioso de los marroquíes y la influencia en ellos de los jerifes; o sea, no solo se debía pensar en la economía, las armas y la recuperación de los empréstitos. En conclusión:

No cuentan con el islamismo, con aquello que Saint-Simon, el genial precursor del movimiento social, llama Pouvoir espirituel constructor de pueblos nuevos y sostén de las razas cansadas y viejas. El islamismo no ha muerto: en estos años, en estos meses, asistimos a un formidable renacimiento de la religión islámica que, bajo los inocentes protectorados europeos, están organizando corporaciones activas y potentes por todo el norte y centro africanos.

Da la impresión de que don José, pensando en los lectores hispanoamericanos, rechaza aquí lo defendido en su artículo anterior; es decir, pretende congraciarse con las gentes del Nuevo Continente que recriminaran a España su colonización siglos atrás.

"Alemán, latín y griego" se publicó en la página cuarta de EL Imparcial el 10 de septiembre. Afirma en él su autor que la iniciativa tomada por Francia de crear una "Liga" para la defensa de su lengua y cultura debiera seguirla España. Pero Ortega y Gasset censura a esa institución que se centre sólo en cuidar la expresión lingüística volviendo al latín y margine la atención al fondo, al contenido, a la verdad de lo que se dice. Para mejorarlo, la "Liga" debiera tomar como ejemplo el uso que hacen los científicos alemanes de la lengua germana.

55 El Imparcial, 14 de junio de 1911, p. 3. 
Cree el autor que a España, "sometida, como vive, a las enseñanzas de las modas francesas, forzosamente han de preocuparle esos ensayos palingenésicos de una parte de la gente gala". Y añade que, a pesar de que la lengua y cultura alemanas también serán superadas, como lo han sido las latinas, ahora se necesita aprender de aquéllas: "Es menester que toda la instrucción superior española, todas las carreras universitarias, todas las escuelas españolas, exijan el conocimiento del idioma alemán. La cultura alemana es la única introducción a la vida esencial" 56.

La reiterada simpatía de Ortega y Gasset por la cultura alemana pasará a ser matizada en dos entregas, después de la lectura del artículo de Pío Baroja del 31 de agosto en El Imparcial. En efecto, el 13 de septiembre, apareció en ese periódico "Una respuesta a una pregunta I", en donde señalaba que, casi a la vez que don Pío escribía “Con el latino o con el germano?”, el había redactado "Alemán, latín y griego" y lo mismo había hecho Ramiro de Maeztu en "Desafrancesados". Esta llamativa coincidencia de artículos no puede deberse a una casualidad "a un capricho, a una humorada personal o a un súbito enojo contra el imperialismo larvado de Francia". Más bien, parece motivada, sigue diciendo Ortega y Gasset, porque España “orienta su faz hacia donde se derrama un poco de luminosidad". Ese foco luminoso es Alemania, pero no su política imperialista. De acuerdo con este criterio se dirige a don Pío con estas palabras: "Lo importante para usted como para mí es la aproximación cultural de España a Alemania. Con ello da usted muestras de una sensibilidad histórica que suele faltar a los universitarios españoles, no hablemos de los políticos". Agrega a lo dicho que ya en los años setenta se intentó este acercamiento entre España y Alemania con el krausismo, pero el catolicismo y el casticismo de aquélla lo hicieron fracasar, pues los españoles pensaban que su país era muy avanzado en todos los campos y no necesitaba de nadie. Con todo España aún se hallaba a tiempo de rectificar y empezar a germanizarse como lo habían comenzado a hacer Francia, por medio de Renán, e Italia con Carducci. A este fin, convoca Ortega y Gasset a tres generaciones: la de Pío Baroja, la siguiente, o sea, la suya, y "la que se anuncia"57.

$\mathrm{Si}$ "Una respuesta a una pregunta I" no presentaba desacuerdos con el artículo de Baroja, la segunda entrega del joven profesor de metafísica en El Imparcial del 21 de septiembre (escrita el día 10), "Una respuesta a una pregunta, II" muestra discrepancias con el novelista vasco fruto de una lectura más reposada de "¿Con el latino o con el germano?", y quizá también de cierta arrogancia de considerar que quien mejor conocía Alemania y la lengua germana era él. De este modo recrimina a don Pío que se incline hacia este país en contra de lo francés sin aportar argumentos serios. Afirma que no es extraño que los artículos de Baroja irriten a los lectores, porque "se manifiesta en ellos un espíritu aventurero y acerbo". Continúa diciendo que el autor vasco simpatiza con Alemania, no porque estime su ciencia, cultura etc., sino por su rechazo de Francia: "Diríase que le interesa a usted más nuestro apartamiento del influjo francés que nuestra positiva aproximación a Alemania, y hay en sus párrafos una enemistad contra Francia que no puedo compartir”. La autosuficiencia del cate-

56 El artículo lo escribió probablemente en agosto porque coincide en gran parte con el contenido del mandado en este mes al diario bonaerense La Prensa, que aparecería en sus páginas el 19 de septiembre. De nuevo el joven catedrático de la universidad de Madrid intenta halagar a los lectores hispanoamericanos al decirles que, el día en que se supere la próxima germanización de Europa, llegará el futuro esperanzador de la cultura argentina. Sin embargo, antes de que alboree esta cultura, los patrioteros franceses creen que la germanización es una enfermedad.

57 «Una respuesta a una pregunta I», El Imparcial; 13 de septiembre, p. 4. 
drático de 28 años arremete también contra Miguel de Unamuno, al que califica de agresivo, petulante y traductor de lo que le interesa para aprovechar la oportunidad de escribir un artículo: "Éste es el sino de quienes no tienen la modestia de aprender, de los 'elegantes', que decía Kant: se convierten en importadores del snobismo europeo y, como hoy está de moda en la frivolidad del viejo continente hablar mal de la lógica, hablarán mal de ella; y cuando mañana vuelva la moda de acariciar la dialéctica contra los más sinceros matemáticos, hablarán bien de aquélla y mal de ésta" ${ }^{58}$.

Poco concuerda, en verdad, este artículo con la llamada en el anterior a la unión de la generación denominada del "98", la suya y la siguiente, con el fin de que España progresase, distanciándose de Francia y aprovechando la cultura alemana ${ }^{59}$.

Hasta el 1 de diciembre de 1911 no hemos encontrado artículos de José Ortega y Gasset en los que tratara de la cuestión colonial o de preferencia por Francia o Alemania. En "El caso Italia", critica sin paliativos la intervención italiana en Trípoli iniciada el 28 de septiembre. Su censura no se detiene en el Gobierno y los políticos italianos, sino que se extiende a la prensa e incluso al pueblo, pues celebra los éxitos de las operaciones militares ${ }^{60}$. Las aseveraciones ex cathedra sobre Italia le originaron una protesta ante el Gobierno español del embajador de aquel país. Como consecuencia, El Imparcial del día siguiente publicó un artículo en el que reconocía que el "el joven (la cursiva es nuestra) catedrático de Metafísica" había utilizado frases duras y que "sus deducciones y juicios revestían a veces cierta sequedad y rudeza". Ortega y Gasset respondió en el mismo diario el día 14 con el título "Más sobre el caso Italia" diciendo que no había pretendido molestar a nadie y que se había mantenido dentro de los límites de la corrección, para concluir que su escrito había sido menos crítico con Italia que los que aparecían en diarios ingleses, franceses, austríacos, rusos, norteamericanos o alemanes.

\section{Manuel Azaña}

Si el joven profesor de filosofía había respondido a los artículos de Baroja en El Imparcial, lo mismo hizo Manuel Azaña el 11 de septiembre en La Correspondencia de España, uno de los pocos periódicos españoles, según el colaborador de Le Temps $\mathrm{S}$. F. Juge, en que no imperaba la francofobia ${ }^{61}$.

58 El Imparcial, 21 de septiembre de 1911, p. 2.

59 El giro dado por Ortega y Gasset respecto a Baroja pudo deberse también a la opinión de éste de que el declive de España se debió al «descubrimiento» de América. “¿Cómo voy a creer que el motivo de nuestra decadencia fue la conquista de América, si todavía no hay nadie en el mundo que sepa qué cosa fue la conquista española de América?". Adviértase que mientras Baroja dice "descubrimiento", Ortega en un lapsus calami (¿?) cambia la palabra por "conquista”. Además, hay que recordar la explicitada por don Pío poca simpatía por los hispanoamericanos que conoció en sus estancias en París. Igualmente procede subrayar que Ortega y Gasset no podía permitir que la ida de España a América hubiera representado un hecho perturbador para aquélla, pues estaba publicando artículos en La Prensa argentina, en la lengua que habían llevado los españoles, y se beneficiaba de ello. Los períodos de sintonía y discrepancia entre el novelista y el filósofo se sucedieron a lo largo de sus vidas. No es éste el lugar de tratar de ellos, pero cabe recordar la larga controversia mantenida a propósito de la novela y su técnica desde que Ortega y Gasset manifestó sus opiniones en 1915 hasta que Baroja la zanjó de manera terminante en 1925 en el prólogo de La nave de los locos. El escritor vasco llamaba mordazmente al catedrático madrileño «ensayista» y le recomendaba que, así como él no se introducía en cuestiones de filosofía, dejara a los novelistas escribir como mejor les pareciera y opinar respecto a la novela según su voluntad.

60 El Imparcial, 1 de diciembre de 1911, p. 1.

61 Véase «L'amitié espagnole », Le Temps, 1 janvier 1912, p. 2. 
Pero antes de centrarnos en los artículos de Azaña publicados en el mencionado diario en 1911, parece oportuno recordar algo previo a su ida a Francia que explicará hasta cierto punto el contenido de esas colaboraciones periodísticas. El 22 de febrero del citado año pidió una beca de la Junta de Ampliación de Estudios para completar su formación jurídica en París. Como la resolución de la solicitud tardaba, no es aventurado pensar que buscara la forma de hacer méritos censurando la poca simpatía de Baroja con el país vecino y sus elogios de la cultura y ciencia alemanas. Con este fin, escribiría "Las arriesgadas proposiciones de Pío Baroja", artículo que publicó La Correspondencia de España doce días más tarde de "¿Con el latino o con el germano?" del escritor vasco. ¿Fue una casualidad que la beca se le concediera a Manuel Azaña diecinueve días después de la aparición de su escrito periodístico?

Al contrario que Pío Baroja, visitante asiduo de París desde 1899 hasta 1911 inclusive, Azaña, a sus treinta y un años, no había traspasado las fronteras españolas; por tanto, la vivencia y observación in situ de lo francés por parte de Baroja era muy superior a lo que pudiera saber Azaña del país vecino. Cabe recordar, además, su conocimiento de la conducta de Francia en Marruecos adquirido cuando, a finales de 1902 y principios de 1903, desempeñó en Tánger la misión de corresponsal de guerra para El Globo, con ocasión del conflicto civil en el Norte de África durante esos años y posteriores.

De los artículos publicados por el Jurista alcalaíno en La Correspondencia de España solo tres se ocuparon de Francia, Alemania y España. Como ya se ha dicho, el primero se titulaba "Las arriesgadas proposiciones de Pío Baroja". Él y los posteriores aparecieron firmados con el seudónimo de Martín Piñol, cuestión merecedora de estudio, pues ninguno de los colaboradores de periódicos de los que nos hemos ocupado suscribió sus artículos ocultando su nombre. Comienza diciendo Azaña en su escrito que el tema "perenne" de enjuiciar la cultura francesa se halla presente en esos días en la prensa. En efecto, Ramiro de Maeztu se había ocupado de este asunto el 28 de agosto y el 6 de septiembre, Pío Baroja el 31 de agosto y el 5 del mes siguiente y Ortega y Gasset varias fechas antes del de Azaña. Don Manuel afirma que de las distintas opiniones acerca de la actitud de Francia en Marruecos quizá sea responsable el "calor" con que se está tratando el tema de la cultura francesa y arroja una andanada contra el autor de "¿Con el latino o con el germano?”:

La robusta pluma de Pío Baroja ha terciado en la cuestión, y con el gracioso desenfado, que es una de sus mayores cualidades de su estilo, lanza, de propia autoridad, un terrible apotegma: sin duda Francia es uno de los primeros pueblos del mundo, mas la influencia francesa es perniciosa en nuestra patria.

Atroz es la dialéctica de Baroja; con cuatro pinceladas traza un cuadro de los males que, a su juicio, el influjo francés nos viene produciendo.

Manteniendo el tono burlesco contra el escritor vasco, algo que éste no le perdonaría nunca, añade: "Admitamos que hay afrancesamiento, para seguir al novelista en sus amenidades"; y continúa defendiendo que en Europa hay dos tipos de civilización: la francesa y la inglesa, mientras los alemanes trabajan para crear la suya, pues aún no la han conseguido, "ignoro si Baroja estará más informado". Para Azaña, se quiera o no, España ha recibido influencia de Francia, igual que asimiló en otro tiempo la de Italia; además, seguirá siendo país de inspiración "mientras haya diferencia de nivel entre los pueblos". Recuerda que en el siglo XVIII, gracias al ascendiente 
francés, surgió en España un cierto movimiento progresista, y considera que el nivel inferior de ésta respecto al país vecino fue el que originó el afrancesamiento de muchos españoles cuando Napoleón irrumpió en la Península, a la vez que, por otra parte, intenta comprender el patriotismo español contra el invasor. Con todo, don Manuel deja ver claro su pensamiento cuando se pregunta retóricamente: “¿Se puede negar que la orientación política del intruso era incomparablemente superior a la de cualquier Gobierno que los españoles de Carlos IV podían haber soñado?"

Prosiguiendo con los años finales del siglo XVIII y principios del XIX en España, frente a la opinión de Baroja el 5 de septiembre en "España, Alemania y Francia" de que Moratín fue un mal imitador de los comediógrafos galos, sostiene Azaña que don Leandro sabía mucho más que otros genuinamente practicantes del "buen gusto" español como Luciano Comella.

Reconoce el alcalaíno que los franceses son injustos con España en sus "juicios ligeros" y desconocimiento del país, pero afirma que no sería bueno desinteresarse de Francia y dirigir la mirada exclusivamente hacia Alemania, algo que están llevando a cabo los snobs que han ido acostumbrando su paladar a las salchichas de Francfort, con lo que tienen mucho adelantado. De los germanos debiera aprender España los métodos de trabajo científico y también admirar su pensamiento y su arte, pero no su carácter "oficial, burocrático y prusiano". Casi al final, para no mostrase tan excluyente, señala que España debe asimilar lo mejor de Alemania y Francia, pues una cultura no tiene por qué excluir a la otra, y, fijándose en el problema marroquí, termina diciendo que no comprende que de estas polémicas traten de desprenderse cuáles y cómo deben ser las relaciones internacionales que han de establecerse entre los países.

Un mes más tarde de haber llegado Azaña a la capital de Francia aparece en $L a$ Correspondencia de España su "Notas de París. El prestigio de las piedras negras" ${ }^{2}$. Confiesa su autor que se siente allí como en "el lugar común, en la casa materna que a nadie niega su sitio junto al fuego [...]. Este placer es el más fino que reserva París a sus hijos espirituales; es decir, a los hombres un poco cultivados de lo que suele llamarse raza latina".

Afirma, justificando sus alabanzas de París, sin haber estado antes allí, que quien llega a la capital de Francia es como si la recordara, no como si la descubriera, pues desde hace siglos su luz irradia por todo el mundo. Esto es, él conoce tan bien la capital de la República, sin haber pasado antes por allí, como los que han vivido en esa ciudad, Baroja entre otros, puesto que la cultura francesa alumbra el orbe: "Todavía, a pesar de las orientaciones novísimas, los dos adarmes de ideas que pudieran ser directrices de la vida espiritual española se han añadido en París, como tantos otros que fecundaron antaño nuestra alma nacional, adormecida o fatigada". Y eleva sus ditirambos al país en que encuentra hasta afirmar que Francia, Italia y España forman un haz de pueblos de "raza latina" (negada tajantemente por Pío Baroja), los cuales "habían hallado una luz eterna para sus lámparas antes que las demás naciones europeas saliesen de un estadio muy próximo al canibalismo". Para él, uno de los elementos comunes de las tres naciones fue el cristianismo ${ }^{63}$. Sus loas a la razonadora

6219 de diciembre de 1911 , p. 1.

63 Este reconocimiento de la religión cristiana como creencia y doctrina de la que participan Francia, Italia y España contrasta en Azaña con manifestaciones posteriores, tal la expresada en el Parlamento el 13 de octubre de 193: "España ha dejado de ser católica". Véase $E l$ Sol del día siguiente, pp. 1 y 5. 
Francia no tienen límites, o sea se extienden hasta el final del artículo, pues concluye diciendo que el día en que desaparezcan las "piedras gloriosas ennegrecidas de París, [Francia] habrá desaparecido [...] y habrá desaparecido también un bello asunto para hacer de vez en cuando, y sin gran coste, un poco de literatura".

La lectura de tantos elogios al país transpirenaico de quien sería presidente de la II República española puede conducir al lector a pensar que pretendía ganarse el cargo de corresponsal en París del diario en que venía publicando sus artículos. Esta deducción acaso la corrobora la información que aporta Santos Juliá de que, además de las tres colaboraciones publicadas a finales de septiembre y una tercera en octubre, La Correspondencia de España recibió dos artículos suyos en diciembre que no le publicó ${ }^{64}$.

Alguna colaboración más del abogado alcalaíno estampó el reiterado diario, ya en 1912, pero sólo una interesa examinar brevemente en este trabajo, por referirse a la relación entre Francia y Alemania. Se trata de la aparecida el 3 de abril, en la segunda página, "Notas de París. Los oradores de la Sorbona". Se pronuncia en ella contra la desaparición de las clases magistrales en la universidad: "Me permito dudar de la posibilidad y conveniencia de este cambio" por el trabajo en seminarios y en equipos. Pero ya antes había declarado, censurando la enseñanza alemana: "Los estudios oficiales franceses se adaptan cada vez más -no sin esfuerzo- a las normas de ultra Rhin (sic). Se multiplican los cursos cerrados, las salas de trabajo, los seminarios, etc. La campaña contra los profanos y los snobs, peste de las aulas francesas, es día a día más enérgica". Leído lo cual, parece indudable que, pese a los deseos contrarios de Azaña, la influencia de Francia estaba dejando paso en muchos dominios a la de su principal competidora.

\section{Conclusión}

La expansión colonial europea en el norte de África en 1911 pudo haber desencadenado un conflicto internacional armado de las dimensiones que alcanzó el de tres años después. Sin embargo, por el momento, el problema quedó reducido a un acuerdo franco alemán y otro galo español, el año siguiente.

De cualquier modo, antes de la firma de esos convenios, las acciones militares de Francia y España en Marruecos en 1911 provocaron unos apasionados enfrentamientos entre los políticos de ambos países, al igual que en los medios de comunicación. A esta disputa se sumaron significados intelectuales de las llamadas generaciones del “98" y del "14", a través de sus artículos en la prensa.

Ramiro de Maeztu se declaró partidario de Alemania y el Reino Unido ${ }^{65}$ y reticente con Francia; Pío Baroja, admirador de la cultura y ciencia alemanas y muy crítico con el país transpirenaico; José Ortega y Gasset, entusiasta del pensamiento

64 Las colaboraciones no publicadas, probablemente anteriores a "Notas de París. El prestigio de las piedras negras", llevaban por título "La dignidad del Parlamento" y "La burocracia". En la primera critica a la Asamblea francesa tras la firma del convenio franco alemán del 4 de noviembre. Véase Santos Juliá, Vida y tiempo de Manuel Azaña, 1880-1940, Madrid, Santillana, 2010, pp. 83-84. Los artículos citados pueden leerse Manuel Azaña: Obras completas, vol. 7, (ed.) Santos Juliá, Madrid, Taurus, 2008, pp. 231-243.

65 En opinión de Pedro Carlos González Cuevas: Maeztu. Biografia de un nacionalista español, Madrid, Marcial Pons, 2003, p. 158, aunque defendía la ventaja intelectual germana respecto a la británica, El Reino Unido "seguía siendo ética y políticamente superior a Alemania". 
y progreso alemanes y muy tibio con Francia ${ }^{66}$. La excepción la representó Manuel Azaña, quien se manifestó de manera incondicional a favor de la República francesa; o sea, tan francófilo como Baroja antifrancés.

En síntesis, puede afirmarse que 1911 significó, no precisamente motivado por España, un episodio más en las reiteradas desavenencias entre los países de uno y otro lado de los Pirineos. Y es que, aparte el empuje cultural, científico y técnico alemán en aquella época, en la Península Ibérica no se habían olvidado todavía: la influencia de las ideas de la Revolución Francesa en la independencia de los territorios americanos, ni las arteras maniobras de Napoleón Bonaparte en Bayona para hacerse con el Reino de España, ni la invasión posterior del ejército galo, ni la restauración de Fernando VII en el trono en 1823, con el apoyo de los "Cien mil hijos de San Luis".

Pocos años más tarde, durante la Gran Guerra, todos, con la excepción de Benavente y Baroja, se pronunciaron, como gran parte de los políticos e intelectuales españoles más significados, a pesar de la neutralidad oficial, a favor de los aliados, bien por simpatía con Gran Bretaña, bien por su inclinación hacia Francia ${ }^{67}$. Don Pío se manifestó en contra de los dos bandos contendientes, aunque se declarara germanófilo, si bien con el sentido de reconocimiento de la cultura y ciencia alemanas, no de su militarismo, expansionismo e imperialismo, que desagradaron poco, por ejemplo, a Jacinto Benavente ${ }^{68}$. Pero entrar en el aludido período significaría traspasar los límites cronológicos impuestos en el presente trabajo.

66 No le falta razón a Inmaculada Ballano Olano al decir: “a juzgar por los testimonios de sus escritos, [lo francés] ocupa junto a lo alemán un lugar privilegiado en su formación, aunque, a menudo, esto último suele eclipsar lo primero, dada la confesada admiración hacia el espíritu y la capacidad teórica alemanes" ("La respuesta de Ortega y Gasset ante las incitaciones de la literatura francesa", Anuario de la Sociedad Española de Literatura General y Comparada, VIII, 1990, p. 41). Por su parte Francisco Javier Zamora Bonilla afirma: "Su germanismo había sido siempre científico, pero no étnico, pues desconfiaba profundamente del pueblo alemán, cuya pobreza intuitiva y su insensibilidad política le parecían insoportables. Mas eso no significaba que confiara más en los pueblos latinos 'pequeñas razas histéricas del sur' frente a las grandes naciones reflexivas del norte"; Ortega y Gasset, Barcelona, Plaza Janés, 2002, p. 118.

67 Coincidimos con Paloma Ortiz de Urbina cuando afirma que "la mayoría de los intelectuales de peso españoles, pertenecían [...] al bando aliadófilo o antigermanófilo. Sin embargo, esto no fue obstáculo para que muchos de ellos se reconocieran todavía, aunque con la boca pequeña, admiradores de la cultura y la ciencia alemanas", "La Primera Guerra Mundial y sus consecuencias: la imagen de Alemania en España a partir de 1914", Revista de Filología Alemana, 15, 2007, p. 205.

68 Un extenso y documentado análisis, matizable en lo que afecta a Baroja, sobre la inclinación de los políticos, periodistas e intelectuales españoles hacia uno u otro bloque en lucha puede leerse en Maximiliano Fuentes Codera, "Neutralidad e intervención. Los intelectuales españoles frente a la Primera Guerra Mundial (19141918)", Pasajes. Revista de Pensamiento Contemporáneo 43, 2014, pp. 22-39. Por su parte, señala Ángel Lázaro: Biografía de Jacinto Benavente, Compañía Iberoamericana de Publicaciones, Madrid, 1930, que el dramaturgo madrileño le confesó durante la Gran Guerra: "No había [en mí] tal germanofilia. Pero me pareció mal que se quisiera hacer de aquello una comedia de magia, donde el genio del bien era Francia y el genio del mal era Alemania". A cualquiera se le alcanza que estas palabras pretenden ser una justificación de su actitud durante la contienda, pues podía haberlas pronunciado durante la contienda, entre 1914 y 1918 , en vez de redactar y firmar el "Manifiesto germanófilo" que publicó El Imparcial el 17 de diciembre de 1915. 


\section{Referencias bibliográficas}

\subsection{Prensa}

El Adelanto

La Correspondencia de España

Heraldo de Madrid

Heraldo Militar

La Mañana

Le Matin

El Imparcial

Nuevo Mundo

El Pais

La Prensa (Buenos Aires)

El Telegrama del Rif

Le Temps

Vida Nueva

La Voz de Guipúzcoa

\subsection{Fuentes secundarias}

Azaña, Manuel: Obras completas, vol. 7, ed. Santos Juliá, Madrid, Centro de Estudios Políticos y Constitucionales-Taurus, 2008.

Bachoud, Andrée: Los españoles ante las campañas de Marruecos, Madrid, Espasa Universidad, 1988.

Ballano Olano, Inmaculada: "La respuesta de Ortega y Gasset ante las incitaciones de la literatura francesa", Anuario de la Sociedad Española de Literatura General y Comparada, VIII, 1990, pp. 39-47.

Baroja, Pío: Paradox, rey, Madrid, Caro Raggio, 1973.

- Final del siglo XIX y principios del XX, Madrid, Caro Raggio, $1982_{\mathrm{a} .}$

- Las horas solitarias, Madrid, Caro Raggio, 1982.

- Juventud, egolatría, Madrid, Caro Raggio, 1985.

- Corresponsalía de Guerra y otros textos olvidados, Madrid, Caro Raggio, 2014.

Blanco Alonso, Ignacio: "El periodismo en la obra de Ortega y Gasset, en el cincuentenario de su muerte", Doxa Comunicación. Revista interdisciplinar de estudios de Comunicación y Ciencias Sociales, 4, 2006, pp. 13-36.

Bonilla Zamora, Francisco Javier: José Ortega y Gasset, Barcelona, Plaza Janés, 2002.

Calvo, Gonzalo: España en Marruecos (1910-1913), Barcelona, Casa Editorial Maucci, 1914.

Corrales Egea, José: Pío Baroja y Francia, Madrid, Taurus, 1969.

De Bruyne, Jacques y Jacqueline Van Praag-Chantraine: «Pío Baroja et les Français», Revue Belge de Philologie et d'Histoire 47, 3, 1969, pp. 906-922.

Fox, E. Inman: Ideología y política en las letras de fin de siglo (1898), Madrid, Espasa Calpe, 1988.

Fuentes Codera, Maximiliano: "Neutralidad e intervención. Los intelectuales españoles frente a la Primera Guerra Mundial (2014-2018)", Pasajes. Revista de Pensamiento contemporáneo, 43, 2014, pp. 22-39. 
Gajate Bajo, María: "Unamuno y la cuestión de Marruecos. ¿Salvación patria o ruina absoluta?", en Ángeles Barrio, Jorge de Hoyos Puente y Rebeca Saavedra (coords.): Nuevos horizontes del pasado: culturas políticas, identidades y formas de representación, Santander, Universidad de Cantabria, 2011, pp. 133-169.

García de Juan, Miguel Ángel: "Pío Baroja y su germanofilia en la conflictiva segunda década del siglo XX", Revista de Literatura, 154, julio-diciembre, 2015, pp. 399-422.

González Cuevas, Carlos: Ramiro de Maeztu: Biografía de un nacionalista español, Madrid, Marcial Pons, 2003.

Gracia, Jordi: José Ortega y Gasset, Madrid, Taurus, 2014.

Iglesias Amorín, Alfonso: “Los intelectuales españoles en la guerra del Rif”, RUHM, 3, 2014, pp. 59-77.

Juliá, Santos. "Literatos sin público: La aparición de los intelectuales españoles", Studia Historica. Historia Contemporánea, 16, 1998, pp. 107-121.

- Vida y tiempo de Manuel Azaña, 1880-1940, Madrid, Santillana, 2010.

Lázaro, Ángel: Biografía de Jacinto Benavente, Compañía Iberoamericana de Publicaciones, Madrid, 1930.

Loureiro Souto, Jorge Luis: Los conflictos por Ceuta y Melilla: 600 años de controversias, Instituto Universitario General Gutiérrez Mellado-UNED, 2015.

Ortiz de Urbina, Paloma: "La Primera Guerra Mundial y sus consecuencias: la imagen de Alemania en España a partir de 1914”, Revista de Filología Alemana, 2007, 15, pp. 193 206.

Pizarroso, Alejandro: "Los medios de comunicación social 1875-1939”, en Ángel Bahamonde (coord.): Historia de España. Siglo XX, 1875-19139, Madrid, Cátedra, 2000, pp. 691734.

Rabaté, Colette y Jean-Claude: Miguel de Unamuno. Biografía, Madrid, Taurus, 2004.

Reig Tapia, Alberto: "Los intelectuales y la guerra civil española. Los casos de Unamuno y Baroja", Historia Contemporánea, 35, 2007, pp. 601-622.

Seoane, María Cruz y María Dolores Sáiz: Historia de la prensa en España, 3. El siglo XX: 1898-1936, Madrid, Alianza, 1983.

Seco Serrano, Carlos: "El problema de Marruecos en el cuadro político internacional", en Historia de Menéndez Pidal. La España de Alfonso XIII. El Estado y la política (19021931). De los comienzos del reinado a los problemas de la guerra, 1902-1922, tomo XXXVIII, vol. 1, 1996, Madrid, Espasa Calpe, pp. 229-286.

Serrano, Carlos: “Los intelectuales en 1900 ¿Ensayo general?”, en Serge Salaün y Carlos Serrano (eds.): 1900 en España, Madrid, Espasa Universidad, pp. 85-106.

Storm, Eric: "Los guías de la nación. El nacimiento del intelectual en el contexto internacional", Historia y política, número 8, 2002, pp. 39-55.

Suárez Cortina, Manuel: La España liberal (1868-1917). Política y sociedad, Madrid, Síntesis, 2006.

Terreros, Gonzalo: Las guerras de Marruecos, Barcelona, Erasmus ediciones, 2014.

Unamuno, Miguel de: "La vida es sueño. Reflexiones sobre la regeneración de España”, La España Moderna, 10 de noviembre de 1898, tomo 119, pp. 69-78.

Urrutia, Manuel María: "Unamuno y la revista Nuevo Mundo (Artículos desconocidos)", Salamanca, Cuadernos de la Cátedra de Miguel de Unamuno, 34, 1999, pp. 161-203. 